\title{
Declaratory Judgments for Libel: A Better Alternative
}

\author{
David A. Barrett
}

Recent empirical studies of the operation of libel law, most notably the pioneering work of Professor Marc Franklin ${ }^{1}$ and the Iowa Libel Research Project, ${ }^{2}$ have demonstrated that we face a libel crisis. As Professor Franklin concludes, "libel law, particularly media libel law, has developed into a high-stakes game that serves the purposes of neither the parties nor the public."3 Yet, having made the case for "radical surgery" in his prior studies, ${ }^{4}$ Professor Franklin now backs away from the operating table.

Although Professor Franklin believes, as I do, that the most promising solution to the hibel crisis is legislative creation of a declaratory judgment remedy, he is unwilling to make that remedy truly effective. This Comment argues that libel defendants-as well as plaimtiffs-should be given the option to choose declaratory relief in suits by public officials and public figures, and thereby to avoid the chilling mipact of limitless damage awards.

I advocate an approacl embodied in H.R. 2846, a federal libel reform proposal introduced by Congressman Charles Schumer in 1985 as a "study bill" to stimulate discussion of alternatives to libel damage actions. ${ }^{5}$ While the use of the declaratory judgment as a hibel remedy

$\dagger$ Associate Professor of Law, Rutgers University School of Law-Newark. A.B. 1971, Harvard; J.D. 1974, Columbia. The author assisted Congressman Charles Schumer in drafting H.R. 2846, the bill discussed in this Comment.

I would like to thank my colleagues James Paul and Wendy Gordon for their thoughtful suggestions, and Jon Kaplon for his research assistance.

1. See Franklin, Good Names and Bad Law: A Critique of Libel Law and a Proposal, 18 U.S.F. L. REv. 1 (1983) [hereinafter Franklin, Good Names]; Franklin, Suing Media for Libel: $A$ Litigation Study, 1981 AM. B. Found. Res. J. 795; Franklin, Winners and Losers and Why: A Study of Defamation Litigation, 1980 AM. B. Found. RES. J. 455. Like Professor Franklin, I will use the terms "libel," "defamation," and "slander" interchangeably.

2. See Bezanson, The Libel Suit in Retrospect: What Plaintiffs Want and What Plaintiffs Get, 74 CALIF. L. Rev. 789 (1986); Bezanson, Libel Law and the Realities of Litigation: Setting the Record Straight, 71 lowa L. REv. 226 (1985) [hereinafter Bezanson, Libel Law]; Cranberg, Fanning the Fire: The Media's Role in Libel Litigation, 71 Iow A L. REv. 221 (1985); Soloski, The Study and the Libel Plaintiff: Who Sues for Libel?, 71 Iowa L. REv. 217 (1985).

3. Franklin, A Declaratory Judgment Alternative to Current Libel Law, 74 CALIF. L. REv. 809 (1986).

4. Franklin, Good Names, supra note 1, at 29.

5. A bill "[t]o protect the constitutional right to freedom of speech by establishing a new action for defamation," H.R. 2846, 99th Cong., lst Sess. (1985). The complete text of this bill is 
had been suggested before, ${ }^{6}$ Professor Franklin gave the idea timely impetus in a 1983 lecture. $^{7}$ His 1983 proposal described a declaratory judgment remedy in some detail, although it did not suggest actual language for a statute. Professor Franklin now presents a proposal in legislative form which adopts the framework and much of the substance of the Schumer bill. ${ }^{8}$ Professor Franklin's new proposal also modifies and clarifies his 1983 proposal in several significant ways, inost notably with respect to restrictions on discovery and proof at trial which I had criticized in an earlier draft of this Comment. ${ }^{9}$

This Comment briefly describes the Schumer and Franklin proposals for resolving the libel crisis. It then suggests an analytical framework which relates the empirically identified defects of the present libel system to the underlying structure of libel law and demonstrates that the declaratory judgment is the most proimising alternative remedy. After establishing an analytical basis for reform, this Cominent addresses Professor Franklim's criticism of the defendant's option and assesses the differences in the way that the Schumer bill and Professor Franklin's proposal would actually operate. In addition, several suggestions for inproving the Schumer bill are made.

\section{I}

\section{Proposed Legislative Solutions to the Libel Crisis}

In many ways, the similarities between the Schumer bill and Professor Franklin's proposal are more significant than the differences. Professor Franklim has said that "legislation is the best hope to develop a workable and fair system of libel law." 10 Althougl he had called his 1983 proposal a "restoration action,"11 it was, in substance, a no-fault

reprinted in Franklin, supra note 3, at 832-35 [hereinafter the Schumer bill]. See 131 CoNG. REC. E3478 (daily ed. July 24, 1985) (statement of Rep. Schumer) ("The legislation is intended to provoke wide-ranging discussion about American libel law and to encourage exploration of alternatives to it.")

6. See, e.g., Freund, Political Libel and Obscenity, reprinted in 42 F.R.D. 437, 491-518 (1966); Hulme, Vindicating Reputation: An Alternative to Damages as a Remedy for Defamation, 30 AM. U.L. Rev. 375, 402-13 (1981); Ingber, Defamation: A Conflict Between Reason and Decency, 65 VA. L. REv. 785, 852-58 (1979); RESTATEMENT (SECOND) OF TORTS $\S 623$, special note on remedies for defamation other than damages (1977).

7. Franklin, Good Names, supra note 1, at 29-49.

8. See Franklin, supra note 3, at 812-13.

9. Id. at 828-31.

10. Franklin, Good Names, supra note 1, at 35; see also Franklin, supra note 3, at 819 ("statutory reform is worth attempting," preferably at state level). See also Cendali, Of Things to Come-The Actual Impact of Herbert v. Lando and a Proposed National Correction Statute, 22 HARV. J. ON LEGIS. 441, 490-92 (1985) (suggesting adoption of national correction statute to reduce litigation); Ingber, supra note 6, at 850,852 (proposing a "model for future handling of defamation" that "has both judicial and legislative applications").

11. Franklin, Good Names, supra note 1, at 40. 
declaratory judgment remedy. ${ }^{12}$ By now employing the language and format of the Schumer bill, Professor Franklin acknowledges that the most promising new remedy under current constitutional $\operatorname{law}^{13}$ is a declaratory judgment in which the defendant's state of mind is not at issue. ${ }^{14}$

12. The name "restoration action" might serve a useful cosmetic purpose by suggesting to libel victims that the action is "a way to restore reputations that [have] been falsely tarnished." Id. As Professor Franklin concedes, however, neither money nor a judicial declaration of falsity can restore a good name. See Franklin, supra note 3, at 814 n.19; see also Rosenblatt v. Baer, 383 U.S. 75, 93 (1966) (Stewart, J., concurring) ("The destruction that defamatory falsehood can bring is . . often beyond the capacity of the law to redeem."); Ingber, supra note 6, at 824-25 ("inancial compensation is not really possible"). In short, marketing labels notwithstanding, Professor Franklin, like Congressman Schumer, proposed a declaratory judgment remedy, as he now acknowledges.

13. Like Professor Franklin, I assume that current constitutional law will not be modified substantially. See Franklin, supra note 3, at 810 . One must recognize, however, that a significant minority view does not accept the holdings of New York Times Co. v. Sullivan, 376 U.S. 254 (1964) and Gertz v. Robert Welch, Inc., 418 U.S. 323 (1974). In fact, two Supreme Court justices recently critized New York Times and Gertz. See Dun \& Bradstreet, Inc. v. Greenmoss Builders, Inc., 105 S. Ct. 2939, 2947-48 (1985) (Burger, C.J., concurring) (“Gertz should be overruled"); id. at 2950 (White, J., concurring) ("[T]he Court struck an improvident balance" in New York Times); see also B. Fein, New York Times v. Sullivan: An Obstacle to Enlightened Public Discourse AND GOVERNMENT Responsiveness to the PEople (1984) (New York Times should be overruled and a negligence standard applied to public figures).

Some media opponents of libel reform do not object in primciple to changes such as the creation of declaratory remedies. But these opponents do fear that legislative consideration of reform proposals will open New York Times to debate and that antimedia forces will push through legislation sharply curtailing present protections of libel defendants. It seems unlikely that the present Supreme Court would uphold legislation directly conflicting with New York Times or Gertz. See, e.g., Philadelphia Newspapers, Inc. v. Hepps, 106 S. Ct. 1558 (1986) (reaffirming Gertz and holding that first amendment requires private-fignre plaintiff to prove falsity). The Court's composition, however, will change, perhaps weakening the support for New York Times and Gertz. See, e.g., Liberty Lobby, Inc. v. Anderson, 746 F.2d 1563 (D.C. Cir. 1984) (Scalia, J.), vacated, 106 S.Ct. 2505 (1986); Tavoulareas v. Piro, 759 F.2d 90 (Scalia, J., concurring), vacated in part, 763 F.2d 1472 (Scalia, J., concurring), reh'g en banc granted, 763 F.2d 1481 (D.C. Cir. 1985). These reform opponents also fear that the relatively balanced reforms suggested by Congressman Schumer and Professor Franklin may be modifled to disadvantage defendants. Accordingly, in building a consensus for libel reform, one must recognize that some opposition to change stems from a belief that the risk of opening the issue of reform to political debate outweighs the benefits that might be achieved.

14. Other, nonlegislative libel reform proposals made in recent years have included not only creative nondamage alternatives, but also numerous suggestions for improving the damage remedy. See Franklin, Good Names, supra note 1, at 37-40. Many of the suggested improvements in the damage remedy are entirely consistent with the creation of new, alternative remedies. Libel reform can and should occur on multiple fronts. See, eg., Anderson, Reputation, Compensation and Proof, 25 WM. \& MARY L. Rev. 747 (1984) (tightly limiting damage judgments); Ashdown, Of Public Figures and Public Interest-The Libel Law Conundrum, 25 WM. \& MARY L. REV. 937 (1984) (redefining the public figure and public official categories); Schauer, Public Figures, 25 WM. \& MARY L. REv. 905 (1984) (same); Franklin \& Bussel, The Plaintiff's Burden in Defamation: Awareness and Falsily, 25 WM. \& MARY L. REv. 825 (1984) (changing burden of proof); Sowle, Defamation and the First Amendment: The Case for a Constitutional Privilege of Fair Report, 54 N.Y.U. L. REv. 469 (1979) (protecting "neutral reportage"); Zimmerman, Curbing the High Price of Loose Talk, 18 U.C.DAVIS L. REv. 359 (1985) (more effectively protecting statements of opinion); Note, The Fact- 
Professor Franklin also recognizes that effective and balanced libel reform would incorporate a number of additional changes. Professor Franklin's new legislative proposal substantially incorporates two reforms proposed in the Schumer bill. First, with some modification, Professor Franklin adopts section 3 of the Schumer bill, which would abolish pumitive damages in all libel actions. ${ }^{15}$ Professor Franklin also adopts in haec verba section 2 of the Schumer bill, which would establisl1 a uniform national one-year statute of limitations for all libel clains. ${ }^{16}$

In addition to these areas of almost complete agreement, botli the Scliumer bill and the Franklin proposal adopt some version of the Enghish rule, which requires the losing party in all libel actions to pay the winner's attorneys' fees. ${ }^{17}$ Although substantial differences exist on the

Opinion Distinction in First Amendment Libel Law: The Need for a Bright-Line Rule, 72 GEo. L.J. 1817 (1984) (same).

15. Compare the Schumer bill, supra note 5, reprinted in Franklin, supra note 3 , at $832-35, \S 3$, with Plaintiff's Optiou Libel Reform Act [hereinafter "POLRA"], § 3(b), in Franklin, supra note 3, at 812-13. Professor Franklin's 1983 proposal advocated abolition of punitive damages. Franklin, Good Names, supra note 1, at 39 n.172. A number of other commentators have made similar suggestions. See, eg., Smolla, Let the Author Beware: The Rejuvenation of the American Law of Libel, 132 U. PA. L. REv. 1, $91-92$ (1983); Van Alstyne, First Amendment Limitations on Recovery from the Press-An Extended Comment on "The Anderson Solution," 25 WM. \& MARY L. REv. 793, 803-09 (1984); Abrams, Why We Should Change the Libel Law, N.Y. Times, Sept. 29, 1985, § 6 (Magazine) at 34, 93.

The Schumer and Franklin proposals differ in that Professor Franklin specifies that punitive damages are barred in actions "for libel or slander or false-light invasion of privacy," while the Schumer bill would apply to "any action arising out of a publication or broadcast which is alleged to be false and defamatory." Professor Franklin's approach clearly abolishes punitive damages in falselight privacy actions. But the Schumer bill indirectly achieves the saine result. Although some courts have indicated that a false-light claim need not allege defamatory meaning, the claims are essentially "duplicative." See R. SACK, LiBEL, SlANDER, AND RELATEd PROBlems 393 (1980). The advantage of the Schumer bill's more general language is that it precludes artful pleaders from claiming punitive damages for causes of action not listed by Professor Franklin but which require proof of defamatory falsehood, such as claims for intentional infliction of emotional distress arising from a false and defamatory statement. See, e.g., Tumminello v. Bergen Evening Record, 454 F. Supp. 1156 (D.N.J. 1978).

16. See the Schumer bill, supra note 5, reprinted in Franklin, supra note 3, at 832-35, $\$ 2$; POLRA, supra note 15 , at $\S 2(\mathrm{a})$. The statute of limitations issue has not generated much comment, but reform is highly desirable. With many media outlets operating on a regional or national basis, a uniform limitations period eliminates forum shopping and benefits all parties by ensuring prompt correction of the public record.

If plaintiffs are genuinely interested in vindicating injury to reputation, it makes no sense to allow the wound to fester for years after the offense. The law should give little weight to any interests that plaintiffs might have in seeking belated damage windfalls or punishing defendants at the end of a long limitations period. A majority of states apply a one-year statute of limitations to libel claims. R. SACK, supra note 15, at 587 (25 states and District of Columbia as of 1980). Thus, the New Hampshire Legislature responded to Keeton v. Hustler, Inc., 465 U.S. 770, 779 (1984), in which the plaintiff "search[ed] for a state with a lengthy statute of limitations," by reducing its sixyear limitations period to three years. N.H. REv. STAT. ANN. $\$ 508: 4$ (II) (1983).

17. The Schumer bill, supra note 5, reprinted in Franklin, supra note 3, at 832-35, \$4; POLRA, supra note $15, \S 4$; $c$. Ingber, supra note 6 , at $854-55$ (proposing declaratory remedy with no fee-shifting). 
fee-shifting aspects of the proposals, ${ }^{18}$ the acceptance of the English rule ultimately may be more significant. Fee-shifting provides the dual benefits of making deserving plaintiffs whole and discouraging frivolous suits. It is essential, moreover, to make the declaratory judgment a feasible remedy for plaintiffs who are not wealthy.

In important respects, the declaratory judgment remedies that would be created under both the Schumer bill and Professor Franklin's new proposal are also similar. Section 1 of the Schumer bill would create a new cause of action permitting a public official or public figure ${ }^{19}$ to bring an action for a declaratory judgment against a media defendant whicl allegedly published a false and defamatory statement concerning the plaintiff. ${ }^{20}$ Professor Franklin's proposal would do the same. ${ }^{21}$

With respect to otlier aspects of the new cause of action, Professor Franklin's legislative proposal adopts the language of the Scliumer bill. No proof of the defendant's state of mind would be required, effectively making the action one of strict liability. ${ }^{22}$ Thus, a public figure could obtain a libel judgment without the burden of proving actual malice as required under current law. ${ }^{23}$ In return for this major expansion in the scope of liability, recovery of dannages would be precluded in the declaratory judgment action, ${ }^{24}$ and its filing would automatically bar the plaintiff from ever asserting any otler claim, including a claim for damages, arising out of the same statement. ${ }^{25}$ Fimally, the plaintiff would liave to prove all elements of the cause of action by clear and convincing evidence. ${ }^{26}$

\footnotetext{
18. See infra notes $155-63$ and accompanying text.

19. For convenience, both categories of plamtiffs are referred to hereafter as "public figures."

20. The Schumer bill, supra note 5, reprinted in Franklin, supra note 3, at 832-35, § 1(a)(1).

21. POLRA, supra note $15, \S 1(\mathrm{a})(1)$.

22. The Schumer bill, supra note 5 , reprinted in Franklin, supra note 3 , at $832-35, \S 1$ (a)(2); POLRA, supra note $15, \S 1(\mathrm{a})(2)$. A plaintiff could obtain a declaratory judgment whether the defendant published the false and defamatory statement knowingly, recklessly, negligently, or even innocently.

23. See infra notes $41-42$ and accompanying text.

24. The Schumer bill, supra note 5, reprinted in Franklin, supra note 3, at 832-35, § 1(a)(3); POLRA, supra note $15, \S 1(\mathrm{a})(3)$.

25. The Schumer bill, supra note 5 , reprinted in Franklin, supra note 3 , at $832-35, \S 1$ (c); POLRA, supra note $15, \S 1$ (d).

26. The Schumer bill, supra note 5 , reprinted in Franklin, supra note 3 , at $832-35, \S 1$ (b); POLRA, supra note 15, $\S 1$ (b). Professor David Anderson has suggested that actual provable harm to reputation should be a required element of the plaintiff's case in all libel actions, on the theory that the only legitimate purpose of such actions is compensating harm to a plaintiff's reputation. See Anderson, supra note 14, at 749. Neither the Schumer bill nor Professor Franklin would require such proof. Since most of Professor Anderson's objections to presuming harm absent proof of reputational injury pertain specifically to damage actions, it is doubtful that they apply to a declaratory remedy. See id. at 749-56. In any event, requiring proof of actual injury in a declaratory action is unwise. As Professor Anderson recognizes, proof of such injury would inject new evidentiary issues into libel cases. Id. at 764-73. While these complications may be warranted when large damage awards are at stake, they would undermine the simplicity of the declaratory action.
} 
There are, however, crucial differences between the declaratory judgment remedies proposed in the Schumer bill and by Professor Franklin. While Professor Franklin proposes the same new cause of action, he would not limit its use either to public-figure plaintiffs or to media defendants. ${ }^{27}$ Although there seems little reason to limit the new action to media defendants, ${ }^{28}$ applying it to all plaintiffs is more problematic. ${ }^{29}$

The Schumer bill also diverges from Professor Franklin's proposal in its most novel aspect-the defendant's conversion option. Professor Franklin would allow only hibel plaintiffs to choose the declaratory judginent remedy. The Schumer bill, on the other hand, would grant media defendants sued by public figures the right to convert the damage action mto a new action for declaratory judgment. ${ }^{30}$ Upon a defendant's election, the plaintiff would be barred from recovering any damages caused by publication of the statement at issue. ${ }^{31}$ Absent such an election by the

27. See the Schumer bill, supra note 5, reprinted in Franklin, supra note 3, at $832-35 \S 1$ (a)(1); POLRA, supra note $15, \S 1(\mathrm{a})(1)$.

28. Professor Franklin cogently argues that the declaratory judgment remedy should apply to suits against all defendants. See Franklin, supra note 3, at 815-16. The problems that nonmedia defendants may face are serious and troubling. To add one exaunple to those Professor Franklin discusses, individual reporters and editors are often named as codefendants with their inedia employer and it makes sense to give all codefendants the same option. Moreover, the Schumer bill, as now drafted, applies only to "the print or electronic media." The ambiguity of the term "media" invites litigation: How much circulation or how large an audience is required? What regularity of operation? These issues can be avoided by deleting the phrase. The discussion in this Comment of the impact of present libel law on defendants focuses on media defendants. Althougl some of the arguinents presented do not apply to all noninedia defendants, the fundamental points would. Thus, I would extend the declaratory judgment remedy to all defendants.

29. Giving certain private plaintiffs, such as wealtly and powerful individuals and corporations, the added reinedy of a declaratory judgment will generate a strong chilling effect. See infra, text accompanying note 152 . Auneliorating this chilling effect is a substantial advantage effected by granting defendants the conversion option, but where less wealtly private plaintiffs are involved, it may be troubling to do so. Many private plaintiffs do not have the media access that characterizes public figures, nor have they sought or benefited froin publicity. See infra notes 128-33 and accompanying text. Moreover, private plaintiffs are more likely to suffer actual pecuniary loss than public figures, Bezanson, Libel Law, supra note 2, at 228, 231, so involuntary elimination of damages may be unore unfair as well. Professor Franklin would minimize the threat to robust debate posed by private figure damage actions by increasing the fault standard from negligence to actual malice. See POLRA, supra note 15, §3(a); Franklin, supra note 3, at 823-25. That cliange, however, will be politically difficult to accomplish. See infra notes 184-86 and accompanying text. A reasonable first step in libel reform is to adopt the defendant's option declaratory judgment only for public-figure plaintiffs. Expansion to private plaintiffs can be considered later in liglt of that experience.

30. The Schumer bill, supra note 5, reprinted in Franklin, supra note 3, at 832-35, § 1(d)(1). The bill provides that the defendant's election must be made at the time an answer is filed or within 90 days of commencement of the action, whichever is earlier. The 90-day period, which would protect the plaintiff in the event that a motion to dismiss is filed prior to an answer, is somewlat arbitrary. A more direct way to achieve the same result would be to require making the election at the time the defendant answers or otherwise moves against the complaint on a ground which postpones its time to answer. See FED. R. Civ. P. 12(b).

31. The Schumer bill, supra note 5, reprinted in Franklin, supra note 3, at 832-35, § 1(d)(2). 
defendant, the case would proceed as a damage action under the actualmalice standard.

Professor Franklin attacks the Schumer bill for giving defendants the power to override a plaintiff's choice of the damage remedy ${ }^{32}$ This criticism is not surprising in tight of the common law's traditional insistence that the plaintiff is master of his or her claim. In this instance, however, tradition must give way to practical necessity. Libel cases are no longer governed by common law principles alone. Current libel law is an incompatible marriage between common law doctrine and first amendment imperatives. ${ }^{33}$ The defendant's option offers the best hope of saving the marriage while strongly protecting reputation and preserving constitutional principles.

\section{II}

\section{SOURCES OF THE LIBEL CRISIS}

\section{A. The State of Mind Problem}

The root of the present libel crisis lies in the fact that reputation can be imjured by words, but the common law offers redress only in the form of money damages. ${ }^{34}$ Indeed, Frederick Pollock remarked a century ago that hibel law "has gone wrong from the beginning in making the damage and not the msult the cause of action." 35 Although similar sentiments have prompted suggestions for nondamage remedies, such as injunctive and declaratory relief proposals, ${ }^{36}$ and retraction and reply statutes, ${ }^{37}$ the

32. Franklin, supra note 3 at 815 n.27, 836-42.

33. For this reason, Professor Franklin's preference for "moving ahead slowly," id. at 827 , on proposals, like the declaratory judgment remedy, "to make major changes in any legal system, especially one several hundred years old," Franklin, Good Names, supra note 1, at 29, rests on faulty premises. The present legal framework for libel suits is a shotgun marriage, not a "legal system." Nor is it "several hundred years old." Modern libel law dates only from the Supreme Court's 1963 decision in New York Times Co. v. Sullivan, 376 U.S. 254 (1963), which imposed constitutional constraints on the common law action for the first time. Thus, current libel law does not reflect the distilled wisdom of centuries, but is rather a contemporary contrivance in need of immediate overhaul.

34. As Justice Stewart lamented, "[I]mperfect though it is, an action for damages is the only hope for vindieation or redress the law gives to a man whose reputation has been falsely dishonored." Rosenblatt v. Baer, 383 U.S. 75, 93 (1966) (Stewart, J., concurring).

35. F. Pollock, The LAW of Torts 210 (1887).

36. See, e.g., Pound, Equitable Relief Against Defamation and Injuries to Personality, 29 HARV. L. Rev. 640 (1916) (injunctive relief); Chafee, Possible New Remedies for Errors in the Press, 60 HARV. L. REV. 1 (1946) (declaratory relief).

37. See, e.g., Donnelly, The Right of Reply: An Alternative to an Action for Libel, 34 VA. L. REV. 867 (1948); Lefiar, Legal Remedies for Defamation, 6 ARK. L. REV. 423 (1952); Barron, Access to the Press-A New First Amendment Right, 80 HARV. L. REv. 1641 (1967). Recent commentators view retraction statutes as ineffective, largely because they offer defendants insufficient incentive to cooperate. See, e.g., R. SACK, supra note 15, at 382; Hulme, supra note 6, at 387-88. The remedy of a compulsory right of reply, absent a judicial finding of defamatory falsehood, was held 
common law damage action still represents the primary means of vindicating injury to reputation.

When the inflationary increase in tort verdicts produced a libel judgment of half a million dollars, the Supreme Court in New York Times Co. v. Sullivan ${ }^{38}$ responded by imposing constitutional constraints on the damage action. The New York Times decision rested on concern that truthful, socially desirable speech would be deterred by the threat of "libel judgments virtually unlimited in amount."39 Such judgments would cause publishers to doubt whether truth "can be proved in court" and to fear "the expense of having to do so."40 Ratlier than reduce this chilling effect by directly limiting the damage amounts recoverable in libel actions, however, the Court chose instead an indirect means: it engrafted a new substantive element onto the existing common law elements of the plaintiff's case, holding that plaintiffs could recover damages only if they proved that the defendant acted with a culpable state of mind. ${ }^{41}$

In the case of public-figure plaintiffs, the requisite state of mind was "actual malice"-publication of a statement with knowledge of its falsity or in reckless disregard of the truth. ${ }^{42}$ With respect to private plaintiffs, the Court in Gertz v. Robert Welch, Inc. ${ }^{43}$ held that a greater state interest in protecting the plaintiff's reputation mandated reduction of the substantive standard to negligence. ${ }^{44}$ Gertz addressed the problem of excessive damages more directly than did New York Times by limiting recovery under the neghigence standard to compensation for "actual injury." Yet even the negligence standard requires some proof of state of mind, and if the plaintiff can prove actual malice, lie or slie can recover presumed and punitive damages. ${ }^{45}$

unconstitutional in Miami Ferald Publishing Co. v. Tornillo, 418 U.S. 241 (1974). A recent proposal essentially attempts to re-invigorate the retraction model. See Cendali, supra note 10.

38. 376 U.S. 254 (1964).

39. Id. at 279 .

40. Id. See Schauer, Fear, Risk and the First Amendment: Unraveling the "Chilling Effect," 58 B.U.L. REV. 685, 705-12 (1978).

41. New York Times Co. v. Sullivan, 376 U.S. 254, 279-80 (1964). Common law libel rules generally treated state of mind as irrelevant to the plaintiff's cause of aetion. If it was relevant at all, it was purely as a defense. See Restatement of ToRTs $\$ \S 558,599,600$ (1938). In only a few states did the common law require proof of actual malice. See New York Times, 376 U.S. at 280 n.20.

42. 376 U.S. at 279-80; Curtis Publishing Co. v. Butts, 388 U.S. 130 (1967).

43. 418 U.S. 323 (1974).

44. Id. at 349-50.

45. Id. The Gertz "limitation" of recovery under the negligence standard to "actual injury" has proven illusory. The Gertz Court defined "actual injury" to include "personal humiliation, and mental anguish and suffering," 418 U.S. at 350; the Court later held that this could mean emotional injury alone. See Time, Inc. v. Firestone, 424 U.S. 448, 458-61 (1976). Thus, the Court kept the door open for virtually unlimited awards for "actual" mental suffering. See Ashdown, Gertz and Firestone: A Study in Constitutional Policy-Making, 61 MiNN. L. REv. 645, 670-71 (1977). 
Two decades of experience with New York Times and Gertz demonstrate that the Court correctly anticipated that fault-based rules would reduce the incidence of damage recoveries. In recent years, damage awards have been upheld in only five to ten percent of all libel suits. ${ }^{46}$ Although this undoubtedly has reduced the chilling effect on the press, a substantial number of plaintiffs who are in fact injured by defamatory falsehoods nevertheless fail to obtain legal redress solely because they are unable to prove fault. ${ }^{47}$ Since the New York Times Court chose to add a new substantive element to the plaintiff's case, this effect on plaintiffs was foreseeable.

More difficult to anticipate was a profound inetamorphosis in the character of libel actions. By requiring plaintiffs to prove fault, the $\mathrm{New}$ York Times and Gertz rules shifted the focus of hibel suits away from the question of falsehood and to the constitutionally inandated question of the defendant's state of mind. As the Iowa Libel Project has now demonstrated, the libel action, theoretically intended to vindicate the plaimtiff's reputation, has becoine an "action for enforcement of press responsibility." ${ }^{28}$ Since seven out of eight hibel suits are now decided on constitutional privilege grounds-that is, the defendant's state of mind"[a]s a practical inatter, the truth or falsity of the challenged statement is no longer pertinent." ${ }^{49}$ Indeed, Justice Stevens's recent dissent in Philadelphia Newspapers, Inc. v. Hepps, ${ }^{50}$ demonstrates how irrelevant falsehood has become. The Court there held that the first amendinent coinpels a private plaintiff to prove that an alleged defaination is false. Justice Stevens's dissent argued, however, that burdening plaintiffs with proof of falsity was unfair because the "antecedent fault determination" would himit the cases in which truth is even considered to those where the defendant has published with soine degree of culpability. ${ }^{51}$ Justice Stevens thus acknowledged the practical irrelevance of truth, even in constitutional adjudication, in all but the small fraction of cases in which the shift in burden of proof would affect the outcome.

The post-New York Times focus on state of mind has raised the stakes in libel actions so high that the chilling effect-the original target of the state of mind defenses-has remained a serious problem, notwithstanding defendants' impressive success rate. ${ }^{52}$ Even if the defendant

46. See infra note 121.

47. See Philadelphia Newspapers, Inc. v. Hepps, 106 S. Ct. 1558, 1563 (1986); Schauer, supra note 40 , at 708 .

48. Bezanson, Libel Law, supra note 2, at 227.

49. Id. at 230, 232 ("Fault, or abuse of the privilege of negligence or [actual] malice, has . . become the gravamen of the cause of action.").

50. 106 S. Ct. 1558,1566 (1986).

51. Id. at 1567 (Stevens, J., dissenting) (emphasis added).

52. See infra notes $64-70,84-87$ and accompanying text. 
avoids damage liability, it must incur the enormous expense of litigating state of mind and may find that the exposure of questionable reporting practices stings almost as much as an adverse judgment. ${ }^{53}$

In addition, state of mind defenses have other deleterious effects. From the viewpoint of the plaintiff, whose primary aim is to set the record straight, state of mind is at best an irrelevancy and at worst an insurmountable barrier. The plaintiff suffers the same ill effects and has the same need for redress whether a falsehood was a calculated lie or merely resulted froin sloppy typesetting. ${ }^{54}$ Yet the present systein forces a plaintiff to undertake discovery and trial of negligence or actual malice and to expend money and energy to prove facts that are wholly tangential to the primary goal of vimdication. ${ }^{55}$ If the plaintiff cannot prove the requisite state of mind, he or she has no remedy whatsoever. Even if the plaintiff wins, the damage award will not include the costs of litigating this irrelevant issue.

\section{B. The High Stakes Problem}

Since New York Times Co. v. Sullivan was decided, the costs of both prosecuting and defending libel suits have spiraled upward. These mcreases are not solely attributable to the expense of litigating the state of mind issues. The trend to higher judgments in libel cases no doubt reflects a general movement toward broader tort liability and higher damages, ${ }^{56}$ but it also involves factors unique to libel cases, including the focus of trial on state of mind. Juries may well perceive, as the Iowa Project suggests, that they are charged with judging the media's responsibility. ${ }^{57}$ Libel juries, no longer merely providing recompense to the plaintiff, are imposing punishment for the defendant's irresponsible conduct.

The media's own instinct to sensationalize news reports of libel claims also contributes to increased verdicts. A prospective juror cannot help but be influenced by repeated media descriptions of absurdly high ad dainnum clauses, such as references to "Westmoreland's $\$ 120$ inillion

53. For example, the jury in Sharon v. Time, Inc., 599 F. Supp. 538 (S.D.N.Y. 1984), found the statement at issue false and defamatory but not published with actual malice. N.Y. Times, Jan. $25,1985, \S 1$, at 1, col. 2. A great deal of the trial focused on Time's editorial practices. See Adler, Annals of Law (Two Trials), THE NEw YORKER, June 16, 1986, at 42 and June 23, 1986, at 34 (criticizing editorial activities revealed in Sharon and Westmoreland cases. Westmoreland v. CBS, Inc., 596 F. Supp. 1166 (S.D.N.Y.), aff'd sub nom. Westmoreland v. Columbia Broadcasting Sys., Inc., 752 F.2d 16 (2d Cir. 1984), cert. denied sub nom. Cable News Network, Inc. v. U.S. District Court, 105 S. Ct. 3478 (1985)).

54. See Gertz v. Robert Welch, Inc., 418 U.S. 323, 395 (1975) (White, J., dissenting).

55. See infra notes 71-81 and accompanying text.

56. See Smolla, supra note 15 , at 22-36.

57. See supra notes $48-49$ and accompanying text. 
damage suit against CBS."58 Constant repetition of these fanciful figures suggests to the public that they have some meaningful relation to damages deserving recompense. ${ }^{59}$ It is no wonder that seven-figure libel verdicts are now almost the norm, and eight-figure verdicts are not uncommon. ${ }^{60}$

Rising litigation costs have paralleled the increase in jury verdict amounts. In part, the rising costs reflect the mcreasmg sophistication of the plamtiffs' bar. In the years immediately following New York Times, defense lawyers quickly ended pubhic-figure hibel cases with motions for summary judgment on actual-mahice grounds. Such motions typically were based on affidavits of the reporter and editor which described the process of mvestigating, writing, and editing the story, and asserted that the responsible persons had no knowledge of the falsehood claimed by plaintiff. If, as often occurred, the plaintiff opposed this factual showing merely by repeating in an affidavit the actual-mahice allegations of the complamt, unsupported by additional facts, the defendant was entitled to summary judgment. The defendant's unrebutted affidavits as to state of mind were conclusive. ${ }^{61}$ This led some members of the defense bar to the unwarranted assumption that the first ainendment virtually mandated summary judgment on malice. It does not.

Plaintiffs' lawyers eventually learned that they could avoid suminary judgment by taking discovery on the state of mind issue. In Herbert $v$. Lando, ${ }^{62}$ the Supreme Court expressly authorized inquiry into the editorial process to prove "actual malice." If the defendant pleads lack of mahice as a constitutional defense, the plaintiff is entitled to probe the facts behind it, just as any other defense. If issues of fact relating to the malice defense are raised, as they frequently are $\mathrm{m}$ depositions or document discovery of defendants, a court may well find summary judgment

58. Virtually every press description of a libel suit includes the ad damnum amount with no indication that it is virtually meaningless. See, eg., Taylor, Cost of Libel Suits Prompts Calls to Alter System, N.Y. Times, Feb. 25, 1985, at A11, col.1 ("News Analysis" referring to Westmoreland's "\$120 million suit" against CBS even after it was discontinued); CBS Hit with \$100-Million Suit over News Story, Broadcasting, Mar. 10, 1986, at 73; Ex-Agent Files $\$ 120$ Million Libel Suit Against Publisher, Publisher's WeEkLy, Nov. 13, 1981, at 11.

59. So ingrained is this practice that even Floyd Abrams, an outstanding libel defense lawyer, has perpetuated it. In a recent popular magazine article, after describing an actual libel settlement of $\$ 1.4$ million and defense costs of $\$ 5$ million in the Westmoreland case-numbers which clearly are meaningful-he referred to ad damnum amounts without criticism or explanation: Governor Janklow's "\$10 million libel action"; Mr. Lakian's suit "for $\$ 50$ million." Abrams, supra note 15, at 90-92. The casual reader will almost certainly infer that the damage claims are equally meaningful.

60. For example, there were 11 verdicts in excess of one million dollars between 1982 and 1984. Libel Def. Resource Center Bull. No. 11, 15 (Nov. 15, 1984) [hereinafter LDRC Bulletin No. 11]; see also infra note 120 and accompanying text.

61. See, e.g., Gospel Spreading Church v. Johnson Publishing Co., 454 F.2d 1050 (D.C. Cir. 1971); Medina v. Time, Inc., 319 F. Supp. 398 (D. Mass. 1970); Washington Post Co. v. Keogh, 365 F.2d 965 (D.C. Cir. 1966).

62. 441 U.S. 153, 176-77 (1979). 
inappropriate. ${ }^{63}$

With summary judgment more difficult to obtain, the costs of defending libel suits have risen substantially. Lawyers' fees and expenses, together with indirect expenditures of personnel time, have escalated to the point that winning a suit may be as costly as losing. The time and energy expended by management and news staff in defending a suit can be enormous. ${ }^{64}$ Reporters and editors often have been effectively transferred to the pubhisher's legal staff, forced to work full time on their own legal defenses. ${ }^{65}$

The insulating effect of libel insurance has also diminished sharply. When Professor Franklin inade his original proposal three years ago, he estimated that about three-quarters of all newspapers and broadcasters carried libel insurance. ${ }^{66}$ Although seventy-five to eighty percent of preimium costs were attributable to defense expenses rather than to payment of damages, those premiums were relatively low. ${ }^{67}$ Today, libel insurance is often unavailable at any cost or, if available, is beyond the means of many small publishers. ${ }^{68}$ Insurers have raised deductibles and lowered coverage maximums. At least one insurer requires twenty percent copayment of defense costs after the deductible has been exceeded. ${ }^{69}$ One major tibel insurance carrier has dropped out of the field entirely and others have ceased writing new policies. ${ }^{70}$

Plaintiffs have faced comparable cost increases. Whether the plaintiff is a public figure or a private individual, hiring a lawyer to sue will be costly. The magnitude of these costs is suggested by reports that Mobil Corporation provided its top executives with an "insurance" policy of up

63. See Anderson v. Liberty Lobby, Inc., 106 S.Ct. 2505, 2514 (1986) (plaintiff can defeat "defendant's properly supported motion for summary judgment" by "offering ... concrete evidence from which a reasonable juror could return a verdict in his favor," evidence sufficient in "caliber" or "quantity to allow a rational finder of fact to find actual malice by clear and convincing evidence"); Hutchinson v. Proxmire, 443 U.S. 111, 120 n.9 (1979) (actual malice "does not readily lend itself to summary disposition").

64. See, eg., Massing, The Libel Chill: How Cold Is It Out There, Colum. Journalism Rev., May-June 1985, at 31.

65. As McClatchy Newspapers editor Frank McCulloch has stated, "The investigativc team no longer exists, not because we're afraid to have it, but because its members have become full-time litigants." Id. at 37.

66. Franklin, Good Names, supra note 1, at 18-20. Professor Franklin noted, however, that the premium strncture was likely to discourage investigative reporting and coverage of controversial stories to a significant degree. Id. at 20-22.

67. Id. at 18-20 (comparing libel premiums and coverage amounts to those for other types of liability insurance).

68. See Baer, Insurers to Libel Defense Counsel: "The Party's Over," AM. LAWYER, Nov. 1985 , at 69.

69. See Hcavner, Developments in Obtaining Insurance, Changing Terms, and Market Restrictions, in MEdia INSURANCE AND RISK MANAGEMENT (J. Lankenau ed. 1985).

70. Id. 
to ten million dollars to cover the costs of bringing a libel suit ${ }^{71}$ after its president, William Tavoulareas, sued the Washington Post. ${ }^{72}$ Even in a simple suit, a plaintiff cannot expect to try a case for less than $\$ 10,000$ to $\$ 50,000$. The alternative is a contingent-fee arrangement, but many lawyers may be mcreasingly reluctant to accept such arrangements, particularly if the suit involves a potentially strong actual-malice defense.

Unlike defendants, libel plaintiffs may compensate for costs by excessively inflating their damage claims. Like a sweepstakes jackpot, the prospect of a multimillion dollar payoff may induce a contimgent-fee lawyer or the plaintiff himself to finance the suit. A plaintiff may also find a backer willing to underwrite legal fees for personal or political reasons. ${ }^{73}$ None of the plaintiffs in three celebrated recent cases paid their own fees, which undoubtedly exceeded a million dollars in each case. In Tavoulareas $v$. Piro, ${ }^{74}$ plaintiff's einployer paid ${ }^{75}$ in Sharon $v$. Time ${ }^{76}$ services were contributed by counsel; ${ }^{77}$ and in Westmoreland $v$. $C B S,{ }^{78}$ the Capital Legal Foundation, a conservative legal action orgamzation supported by contributions, served as counsel with law firm volunteers. ${ }^{79}$ Carol Burnett complained that even a $\$ 200,000$ damage award was not enough to offset her legal fees. ${ }^{80}$ These experiences and others suggest that serious libel litigation under the present legal rules is beyond the means of even relatively wealthy individuals. ${ }^{81}$

71. Sanger, Tension on the Frontiers of Libel, N.Y. Times, Dec. 18, 1983, § 6, at 4, col. 2.

72. See Tavoulareas v. Piro, 759 F.2d 90, vacated in part, 763 F.2d 1472, reh'g en banc granted, 763 F.2d 1481 (D.C. Cir. 1985).

73. See Roper, Who's Behind the Media Libel Suits?, EdITor \& Publisher, Mar. 2, 1985, at 9 (discussing conservative nonprofit organizations supporting libel suits); "Friends" Chip in for Laxalt, Editor \& Publisher, Apr. 5, 1986, at 14 (Senator Laxalt's suit against the Sacramento Bee alleging $\$ 250$ million damages financed by contributions of $\$ 263,670$ during 1985 froin "friends" ranging from Senators Kennedy and Inouye to Roy Cohn and T. Boone Pickens).

74. 759 F.2d 90 (D.C. Cir. 1985).

75. Hanson, What Went Wrong at the Washington Post, Colum. JouRNalism REv., Jan.-Feb. 1983 , at 31 .

76. 599 F. Supp. 538 (S.D.N.Y. 1984).

77. Adler, supra note 53, June 16, 1986, at 48.

78. 596 F. Supp. 1166 (S.D.N.Y. 1984).

79. Roper, supra note 73. After the Westmoreland ease ended, there were reports that Capital Legal Foundation counsel had urged settlement strongly, without discussing it with Westmoreland's private firm counsel, as a result of the Foundation's political agenda or financial situation. See Bruck, How Dan Burt Deserted the General, AM. LAWYER, Apr. 1985, at 117. This suggests the danger that confiict of interest may pose for a plaintiff who is not paying counsel directly.

80. Franklin, Good Names, supra note 1, at 39 n.176; see Burnett v. National Enquirer, Inc., 144 Cal. App. 3d 991, 193 Cal. Rptr. 206 (1983), appeal dismissed, 465 U.S. 1014 (1984).

81. Former Congressinan Andrew Maguire recently described his frustration at being financially unable to do inore than threaten to sue book publisher William Morrow \& Co. The authors of the offending book formally acknowledged their errors, and the publisher promised not to reprint accusations that Maguire had improperly hindered a congressional investigation of inob corruption in the toxic waste industry, and reimbursed Maguire's legal fees. Maguire believes, however, that Morrow was unwilling to negotiate a stronger, more public remedy, such as retraction or withdrawal of the book, because Morrow knew that he could not afford to sue. Hearings on H.R. 
The perceived need of plaintiffs to inake enormous damage claims creates a vicious cycle. Even if the defendant believes the possibility of losing the action is reinote, the size of the claim forces the defendant to defend itself vigorously. Such full-scale defense, often conducted by a top law firm in the manner of a major securities or antitrust action, ${ }^{82}$ in turn compels a serious plaintiff to hitigate with equal fervor and to claim still greater damages.

A defendant which knows it cannot afford to mount such a largescale libel defense has few choices. It may be forced to settle, admitting error where none existed, thus damaging its own reputation. It may litigate less aggressively and risk an adverse verdict that could lead to bankruptcy. ${ }^{83}$ The most probable response, however, is for the defendant to try to minimize the risk of hibel suits altogether. To the extent that this entails pubhishers taking greater care in gathering information, writing, and editing, libel law is performing an appropriate deterrent function. But mounting evidence indicates that, apart from certain "large and profitable" media defendants which deny any impact on their editorial practices, many publishers and broadcasters are feeling a significant chilling effect. ${ }^{84}$ Inportant news, responsible coininentary, and political advocacy inay not be reaching the public. For example, apparently out of fear of libel suits, some twenty scientific journals declined to publish a study by scientists at the National Institutes of Health which criticized the inethodology of other prominent researchers. ${ }^{85}$ Newspaper and magazine publishers acknowledge decisions not to run controversial stories that they believed to be true but could not economically afford to stand behind. ${ }^{86}$ Fear of hibel suits is also silencing citizens' criticism of power-

2846 [the Schumer bill]. Before the Subcomm. on Civil and Constitutional Rights of the House Comm. on the Judiciary, 99th Cong., 2nd Sess. (1986) (statement of Andrew Maguire) (on file with the author) [hereinafter 1986 House Hearings].

82. See Baer, supra note 68.

83. See, eg. Green v. Alton Telegraph Printing Co., 107 Ill. App. 3d 755, 438 N.E.2d 203 (1982); Smolla, supra note 15, at 12-13 (commenting on Alton Telegraph case).

84. Franklin, supra note 3, at 810; Franklin, Good Names, supra note 1, at 16.

85. 1986 House Hearings, supra note 81 (statement of Walter W. Stewart \& Ned Feder, M.D.); Boffey, Major Study Points to Faulty Research at Two Universities, But, Amid Fears of Libel, It Has Not Been Published, N.Y. Times, Apr. 22, 1986, at Cl, col. 4; Abrams, supra note 15.

86. See, e.g., Massing, supra note 64; Libel-The Intimidation Factor, THE CENTER MAGAZINE, May/June 1985, at 33 (chilling effect on small media); id. at 35 (quoting David Lawrence, Detroit Free Press publisher: "[T]he threat of libel . . . is very chilling, intimidating and frightening, ... more so than it has ever been before ... even for an aggressive and honest publisher."); Abrams, supra note 15, at 92 (quoting Osborn Elliott, Dean of Columbia Graduate School of Journalism: "Care and caution are giving way to timidity in newsrooms across the land."); 1986 House Hearings, supra note 81 (statement of Homer F. Marcum, editor and publisher of The Martin Countian, Inez, Ky.) ("Each time I paste up a story on my front page, or an editorial that is somewhat controversial, I stop to think 'Is it worth it?' My financial resources are ... such that I cannot say yes too many more times when some burning issue in my community needs the benefit of a strong editorial voice."). 
ful community figures. ${ }^{87}$

\section{Social Costs of the Present Libel System}

The enormous costs that libel suits impose on the rest of society are no less significant in justifying reform. Like the high-stakes problem, these social costs flow primarily from the state of mind defenses, but they have an impact far beyond the parties theinselves.

The most obvious social cost of libel damage awards is the chilling effect on the press, which leads to reduced investigative reporting and reduced coverage of controversial issues and personatities. ${ }^{88}$ Less apparent social costs include not only the largely wasted transaction costs of administering the damage systein, but also the price paid under the current system in the form of public cynicisnı regarding press accuracy and the integrity of public figures and officials.

The high transaction costs associated with libel damage actions include the costs of providing judges, courtroonis, jurors and court persoimel to hear coniplex cases generated primarily by the state of mind defense. ${ }^{89}$ Although lawyers' time is generally assumed to be infinitely expandable, soine distortions inust arise as time and resources are diverted fronı other tasks to hibel suits. The Iowa Libel Project indicates the extent of these transaction costs in its findings that pretrial motions involving privilege issues "are made in virtually every" hbel case, and in about half the cases, an interlocutory appeal is taken froin the trial court's decision on these issues..$^{90}$ Moreover, privilege claims are presuinably at issue in every one of the twenty to twenty-five percent of libel cases that reach trial, and virtually all cases are appealed after trial. ${ }^{91}$ Ultimately, state of imind defenses determine the outcome in eighty-eight percent of all inedia libel cases. ${ }^{92}$

In addition to direct transaction costs, libel suits today generate large social costs in the form of increased public cynicisin. Because truth has become alnıost irrelevant in hibel actions, the press has lost credibility; political leaders and public figures have lost respect; and the legal

87. See, e.g., Franklin, supra note 3, at 809 n.5, 815 n.24; Hearings on Libel Reform Before the House Judiciary Subcomm. on Courts, Civil Liberties and the Administration of Justice, 99th Cong., lst Sess. (1985); (Statements of Gene Roberts, Executive Editor, The Philadelphia Enquirer, and Bruce J. Ennis) (on file with the author).

88. See supra notes 83-86; Franklin, supra note 3, at 811; Franklin, Good Names, supra note 1, at $13-22$.

89. These so-called "tertiary costs" of administering any system of legal redress for injuries are largely wasted under the present damage rules because little compensation flows to persons who are actually injured by false statements. See Ingber, supra note 6, at 814 .

90. Bezanson, Libel Law, supra note 2, at 227 \& n.1, 231.

91. Id.

92. Id. at 230,232 ("Questions of constitutional privilege are raised in virtually every case and are determinative in eighty-eight percent of the cases."). 
system is viewed as having elevated technicality over principle. The pubhic has no way of discerning whether news stories that becoine subjects of libel suits are true or false.

Since seven of eiglit libel suits turn on state of mind issues, ${ }^{93}$ a plaintiff who is the subject of a lighly damaging, but essentially truthful, report can persuade the public that the report is false, without risking exposure of the truth, merely by filing a libel suit. According to the Iowa Project, public figures believe that the very act of bringing suit is a powerful form of reply and vindication. ${ }^{94}$ The general public, already distrustful of the institutional press, is likely to believe the allegation of false reporting in the coinplaint. The "guilty plaintiff"-perhaps an organized crine figure or a corrupt politician-can be confident that pretrial proceedings will be lengthy, averaging more than four years, because of issues injected by state of mind defenses. ${ }^{95}$ Even if the challenged statement is eventually found to be true, that finding will come too long after the publicity to be of consequence. And if, as is far more coinmon, the plaintiff loses not on truth but on a privilege clain, the plaintiff is free to maintain the posture of innocent victim by arguing that the defendant was saved by a technicality. ${ }^{96}$

Current law thus encourages the least worthy plaintiffs to sue by virtually eliminating any risk of a judgment confirming the truth of the cliarges against them. At the saine time, the present law and social climate offer undeserving plaintiffs substantial vindication by the inere act of suing the media. ${ }^{97}$ By merely filing complaints, undeserving plaintiffs can mislead the public into assuming that their clains have merit and immediately undermine the defendants' credibility. Even if the defendant ultimately wins on a inalice defense, its credibility may not be fully restored because malice may be perceived as a legal "technicality." Nor is the inference of falsity created by the complaint ever rebutted.

The distortions created by the focus on state of inind also inake the current dainage action almost wortliless to an honest victim of a defainatory falsehood. That plaintiff faces less than a ten percent chance of ever seeing the falsity claim adjudicated, while spending years in expensive litigation over state of inind. Only rare individuals will take on such

93. Id.

94. Id. at 231.

95. Id. "Privilege issues ranging from discovery, access to information, legal status of the plaintiff, and negligence and actual malice, exist and must be addressed in every libel case brought against the press."

96. Id. at 230.

97. As the Iowa Study reports, a "substantial majority of [public figures] believe that the lawsuit achieved reputation-related objectives, even though they lost." Id. at 231. Furthermore, public figures remain "virtually unanimous in their determination to sue again if faced with the same situation." Id. 
daunting odds. In most cases, the false statement is never corrected or adjudged, so that not only is the plaintiff's reputation besmirched, but future public discussion is distorted by the uncorrected falsehood.

III

The Declaratory Judgment Solution

\section{A. Advantages of Declaratory Judgments in Libel Actions}

The creation of a declaratory judgment remedy is a particularly appropriate solution for the hibel crisis because it is precisely targeted at the sources of the crisis identified above. Declaratory judgment actions focus primarily on the accuracy of the challenged statements. Irrelevant inquiry into why or how an error was made would no longer be necessary.

Denymg plaintiffs the right to damages is a fair price to exact in return for the creation of a far more efficient method of vindication. ${ }^{98}$ In contrast to their currently dismal five to ten percent success rate, ${ }^{99}$ plaintiffs may well win most declaratory judgment actions. With such a swift and sure remedy, plaimtiffs who sue are likely to be quite confident of their claims and suits by "guilty plamtiffs" should decline. From the defendants' perspective, the threat of bankrupting damage judgments will be reduced under the Franklin proposal and eliminated by the Schumer bill. With millions of dollars in potential liability no longer at stake, litigation costs will plummet, hastened by the attorneys' fee-shifting provisions included in both proposals. The chilling effect of potential liability on the press should therefore diminisli considerably. ${ }^{100}$

Fimally, declaratory judgments will serve the public interest by allowing courts to make prompt determinations of accuracy. Transaction costs will be reduced, and the false statement-whether made by the defendant's challenged report or by the plaintiff's complaint of falsity-

98. The declaratory judgment action must bar a damage action based on the same claim, or the potential chilling effect of the new remedy would be enormous. Not only would the defendant face strict liability in the declaratory judgment action, but it would also continue to face the risks of a large damage recovery.

99. See Soloski, supra note 2, at 218; Bezanson, Libel Law, supra note 2, at 228; Franklin, Good Names, supra note 1, at 5; infra note 121 .

100. One can view the declaratory judgment remedy as a kind of market solution to the problem of reputational injury. Since there is no possibility of a damage windfall, both parties will gear their level of financial and personal commitment to the lawsuit in terms of the perceived value of restoring or maintaining their own reputations. A plaintiff who is genuinely concerned about his or her reputation will tend to spend more money to protect it than one who is less committed, but who under the present system might be tempted by the prospect of large damages to litigate more aggressively. Similarly, a defendant that is strongly committed to protecting its reputation for accuracy will expend more time and money on defense than one to which reputation is less important. But the calculus will be tied directly to the perceived value of the defendant's reputation, not skewed, as it is today, by the risk of enormous damages. 
will quickly stand exposed. Accurate information will strengthen the quality of public debate and will discourage unfounded suits by guilty plaintiffs.

The notion that some plaintiffs must forego monetary compensation for reputational injury in the interest of implementing broader social goals is not new. The common law of libel has always recognized privilege defenses as a means of implementing other social goals. ${ }^{101}$ Traditionally, absolute privileges bar recovery altogether, no matter how deserving the plaintiff. ${ }^{102}$ Absent a showing of the defendant's bad faith, qualified privileges prevent recovery in many cases where the plaintiff has undoubtedly suffered serious reputational injury, including provable special damages. ${ }^{103}$ Unlike these common law privileges, which preclude all relief, a declaratory judgment action will enable public figures to obtain a judgment of falsity where appropriate even thougli damages would not be recoverable. ${ }^{104}$

\section{B. Evaluating the Defendant's Option and Professor Franklin's Proposal}

The justifications for a declaratory judgment remedy warrant implementing it broadly. Professor Franklin acknowledges this goal wlien he asks whether plamtiffs will in fact choose the declaratory judgment option and when he discusses ways im which to make damage suits less attractive and declaratory judgments more appealing. ${ }^{105}$ The Scliumer bill does inore than merely recognize this goal. By giving defendants, as

101. See R. SACK, supra note 15, at 267-339.

102. Id. at 268.

103. See id. at $328-38$.

104. Professor Franklin concludes that the state statutory and common law absolute privileges should be recognized as defenses to a new declaratory judgment action. Franklin, supra note 3, at 817-18. He is inchined "to leave [qualified] privileges in place as well." Id. at $818 \mathrm{n} .35$. One could argue, however, that because qualified privileges do not protect interests as important as the absolute privileges, a plaintiff should have the opportunity to correct the record in a declaratory judgment action.

Professor Franklin relegates the fair comment and opinion privileges, see, e.g., RESTATEMENT OF TORTS $\S 606$ (1938); RESTATEMENT (SECOND) OF TORTS $\S 566$ (1976), to a footnote. Franklin, supra note 3, at 818 n.35. Whether they are labeled privileges, as most courts still do, or "part of the plaintiff's case," as Professor Franklin urges, fair comment and opinion should be recognized in declaratory actions. They protect speech that is not demonstrably "true" or "false," and are probably constitutionally compelled, at least in damage actions. See Ollman v. Evans, 750 F.2d 970 (D.C. Cir. 1984), cert. denied, 105 S. Ct. 2662 (1985). The values thus protected-the speaker's personal autonomy and the impracticability of proving opinions "true"-would be compromised if a declaratory judgment action did not recognize them.

Although Professor Franklin discusses privileges, he does not respond to the main point of the text-that the common law privileges deny recompense to some deserving plaintiffs in order to protect other, overriding societal interests. Professor Franklin's endorsement of privileges is thus somewhat inconsistent with his criticism of the defendant's option in the Schumer bill, which would have an effect no different in kind from that of the privileges on plaintiffs' ability to obtain relief.

105. Franklin, supra note 3 , at 825-27. 
well as plaintiffs, the option to choose a declaratory judgment, the bill creates a remedy that forcefully implements the goal.

Professor Franklin's objection to the defendant's option partly stems from his assessments of the sources of the libel crisis described earlier. For example, Professor Franklin acknowledges the problems of high stakes and chilling effect, ${ }^{106}$ but apparently feels we can live with them during years of experimentation with limited new remedies. Many small publishers may not last that long, however, and large media outlets are daily becoming more bland and timid. ${ }^{107}$ Professor Franklin also recognizes the social costs of damage actions, ${ }^{108}$ but because he fears "irresponsible publishers," 109 he stops short of reducing those costs as much as possible. Lastly, Professor Franklin refuses to move forcefully to eliminate state of mind issues from libel actions. He focuses instead on the importance of preserving a public figure's absolute right to seek damages from a publisher who engages in "imtentional defamation." 110

Professor Franklin overrates the importance of damages as a remedy to public figures and as a deterrent to irresponsible pubhishers. $\mathrm{He}$ underestimates the social costs of hibel actions and the dangers of high stakes and chilling effect. Allowing defendants the option to convert damage actions to declaratory judgments will reduce these costs and dangers far more effectively. Although a few potential public-figure plaintiffs may be deprived of damages that reflect actual harm, the overall benefits to society of allowing conversion will greatly outweigh the hardship to these few plaintiffs. Furthermore, the first amendment, all but ignored by Professor Franklin, strikes a balance in favor of truthful communication that would otherwise be chilled. As the Supreme Court recently noted, "where the scales are in ... an uncertain balance, ... the Constitution requires us to tip them in favor of protecting true speech."111

\section{Fairness to Plaintiffs}

Professor Franklin argues that the defendant's option is "unfair" because plaintiffs "who have suffered harm will be effectively barred from suing for damages by the likelihood that these dainage cases will be converted into declaratory judgment actions."112 This concern for "fairness" is greatly exaggerated. First, as Professor Franklin elsewhere acknowledges, a serious problem is posed by "organizations and individuals who are mainly interested im harassing defendants" by maintaining

\footnotetext{
106. Id. at $810,811,838$.

107. See supra note 86.

108. Franklin, supra note 3, at 841; Franklin, Good Names, supra note 1, at 30.

109. Id. at $838-42$.

110. Id. at 840 .

11. Philadelphia Newspapers, Inc. v. Hepps, 106 S. Ct. 1558, 1564 (1986).

112. Franklin, supra note 3, at 837.
} 
cases "they cannot realistically win." 113 Only the defendant's option will effectively deter suits by these plaintiffs.

If Professor Franklin is worried that plaintiffs who have suffered special damages will be denied recovery, as suggested by his proposal to bar shifting attorneys' fees to losing plaintiffs who "sustained special damages," 114 his concern is misplaced. The reality of litigation under current libel law demonstrates that plamtiffs "who have suffered harm" in the form of actual pecuniary loss are not necessarily those with good "damage cases," which require proof of actual malice. Where the malice defense applies, deserving plaintiffs do not actually recover appropriate damages with significant frequency because of the difficulty of proving mahice.

Conversely, not all plaintiffs who happen to be able to prove actual malice will have suffered significant "harm." The actual reputational impact of a lie may be small, but given the vagaries of jury verdicts, the potential recovery may be enormous. ${ }^{115}$ Yet Professor Franklin would allow these plamtiffs to sue for general dainages of unlimited amount, ${ }^{116}$ thereby perpetuatimg the significant chilling effect. Given the recognized potential for abuse of general damages, ${ }^{117}$ Professor Franklin's failure to consider their abolition, much less to justify maintaining them, seriously weakens his proposal. ${ }^{118}$

A further einpirical consideration in evaluating the defendant's option is that, at present, hibel plamtiffs have virtually no chance of obtaining meaningful monetary recompense for "harm" they may have suffered. Libel complaints regularly allege astronomical damages. ${ }^{119}$ While verdicts averaged froin $\$ 2$ imillion to $\$ 3$ inillion between 1980 and $1984,{ }^{120}$ after completion of the appellate process, only five to ten percent of plaintiffs retain damage judgments. ${ }^{121}$ A comprehensive survey of

113. Id. at 826; see also Franklin, Good Names, supra note 1, at 5-6 (reporting estimate that half of all libel cases are "nuisance" cases).

114. POLRA, supra note 15, §4(b)(1); see also Franklin, supra note 3, at 842.

115. Professor Van Alstyne has suggested that the actual-malice defense makes it more likely that the rare plaintiff who gets to trial will win. Because the defendant's fault is an issue for the jury, a skillful plaintiff's lawyer can turn the trial's focus to the defendant's alleged misconduct. The jury may well feel that the misconduct, and not the injury to the plaintiff, is the gravamen of the tort. Moreover, by forcing the plaintiff's lawyer to prepare the malice claim more fully, the defense may also indirectly encourage large verdicts. See Van Alstyne, supra note 15, at 795-98.

116. See Franklin, Good Names, supra note 1, at 38.

117. See supra note 45 .

118. Also significant in this regard are the normative considerations that apply to voluntary public figures. See infra note 128-133 and accompanying text.

119. See, e.g., Smolla, supra note 15, at $2-4$ (reviewing multimillion dollar libel claims).

120. Goodale, Survey of Recent Media Verdicts, Their Disposition on Appeal, and Media Defense Costs, in Media Insurance and Risk MANAgement 1985 at 69, 78 (1985); Libel Defense Resource Center Bulletin No. 12, (Dec. 31, 1984) [hereinafter LDRC Bulletin No. 12].

121. Bezanson, Libel Law, supra note 2, at 228; Franklin, Good Names, supra note 1, at 4-5. 
libel decisions between 1982 and 1984 showed that only two verdicts under the malice standard were ultimately affirmed, for damages totaling just $\$ 42,500 .{ }^{122}$ These statistics indicate that few public-figure plaintiffs would lose significant actual recoveries if damage suits were largely eliminated through the defendant's option. ${ }^{123}$

The Iowa Libel Research Project supports this conclusion in its findings that the "dominant interest of most libel plaintiffs is correction of falsity," 124 and that "inoney seems rarely to be the reason for suing." 125 Large damage claims appear to serve two purposes in plaintiffs' minds. First, plaintiffs may wish to punish the pubhisher or "to get even." 126 To the extent this means that plaintiffs are trying to silence annoying critics rather than to recover for actual mjury or correct the record, it is an illegitimate purpose that the law need not countenance. In any event, the chilling effect of massive damage claims and occasional verdicts on all publishers, not just on the libel defendant, is a very high price for society to pay for a victim's dubious satisfaction im "getting even."

A inultimillion dollar dainage claim may also serve the victim's interest by securing publicity and providing a sense of vindication. The Iowa study indicates that " $[\mathrm{m}]$ ost plaintiffs win by suing .... The very act of [filing] suit, itself, represents the only non-self-serving forn of response through which plaintiffs' claims of falsity can be legitimized ...."127 A declaratory judgment action, however, would serve exactly this purpose at far less cost to all parties and to society.

Professor Franklin's criticisin of the defendant's option also downplays the fact that the Schumer bill limits the option to suits brought by

Statistics suggest that in the period 1982 to 1984 , plaintiff' ultimate success rate dropped even lower-to less than three percent. See LDRC BuLLETIN No. 11, supra note 60.

122. LDRC BuLletiN No. 12, supra note 120. The total number of libel damage awards affirmed between 1982 and 1984, including actual-malice and negligence cases, was six, with an average award of about $\$ 60,000$. These figures are substantially lower than the 14 awards affirmed between 1980 and 1982 for an average award of $\$ 120,000$, suggesting a trend toward fewer and smaller awards. Between 1980 and 1982 only 7 of the 14 affirmed awards occurred in cases in which the actual-malice standard was dispositive, so that only nine "malice" awards were finally upheld over a four-year period. Id.; LDRC BuLLETIN No. 11, supra note 60, at 22, 23.

123. Indeed, because Professor Franklin would require all plaintiffs, including private figures, to prove actual malice in order to recover any damages, few private plaintiffs would lose much if the defendant's option were applied to them. See POLRA, supra note 15, § 3(a), Franklin, supra note 3, at $823-25$.

124. Bezanson, Libel Law, supra note 2, at 233.

125. Id. at 227.

126. Id.

127. Id. at 233. By filing suit, plaintiffs feel that they are transformed from victim to active fighter for truth and honor: "'You walk into the halls and people you've known for years feel sort of sorry for you. ... But the moment I sued, the attitude of everybody changed. ... Suddenly people started to believe you. My days changed the day I started the suit' " Brill, Inside the Jury Room at the Washington Post Libel Trial, AM. LAWYER, Nov. 1982, at 1, 90 (quoting Mobil Corp. president William P. Tavoulareas). 
public figures. ${ }^{128}$ The unique role of public figures in modern society justifies the bill's departure from the usual pattern of allowing the plaintiff to control the form of action. The Supreme Court in Gertz recognized that public figures "invite attention and comment."129 Although publicity about a public figure occasionally may cause reputational injury, far more often a public figure needs and wants publicity and will go to great lengtlis to obtain it. Publicity wins votes and persuades followers. It sells movies, automobiles, and baseball tickets. It gives the subject a sense of power, importance, and satisfaction. Publicity is the lifeblood of the public figures.

In exchange for the benefits of publicity, public figures "accept certain necessary consequences of that involvement... [including] the risk of closer public scrutiny than might otherwise be the case."130 Public figures almost invariably are in the public eye precisely because they have chosen to "assuine ... roles of especial prominence in the affairs of society." 131 By seeking publicity, they "have voluntarily exposed themselves to mcreased risk of injury from defainatory falseliood."132 Because they liave sought the spotlight and benefited greatly from it, it is reasonable to compel public figures to give up dannages in return for effective protection from defainatory falselioods. ${ }^{133}$

128. See supra note 29 and accompanying text. Although there is considerable debate over the contours of the public figure doctrine, the Schumer bill does not attempt to define this elusive term. See, e.g., Ashdown, supra note 14; Daniels, Public Figures Revisited, 25 WM. \& MARY L. REV. 957 (1984); Schauer, supra note 14. Instead, the bill accepts the current doctrine as at least minimally fair and workable, although judicial modification of it would change the scope of the bill's applicability. See infra note 133 .

129. Gertz v. Robert Welch, Inc., 418 U.S. 323, 345 (1974).

130. Id. at 344 .

131. Id. at 345 .

132. Id.

133. Gertz also distinguishes public figures from private persons because the former "usually enjoy significantly greater access to the channels of effective communication and hence have a more realistic opportunity to counteract false statements" without bringing libel suits. Id. at 344 . This access to the media also reduces the strength of the public figure's claim for damages.

Applying these arguments to lower level appointed public officials, such as school teachers, sanitation workers, and government clerks, as well as to private figures, is problematic. Despite indications from many lower courts that all government employees are public officials, this may be too broad a reading of the Supreme Court's decisions. See Elder, Defamation, Public Officialdom and the Rosenblatt v. Baer Criteria-A Proposal for Revivification: Two Decades After New York Times Co. v. Sullivan, 33 Buffalo L. REV. 579, 678-79 (1984). Although one never becomes a public official at any level involuntarily, lower level employees cannot generally be described as seeking and benefiting from the spotlight of publicity. On the other hand, the impact that certain persons and corporations, particularly those of great wealth and power, now classified as private figures have on the community could well justify treating them as public figures.

Professor Franklin's concern for "involuntary" public figures is greatly overstated. See Franklin, supra note 3, at 840 n.127. "The instances of truly involuntary public figures must be exceedingly rare." Gertz v. Robert Welch, lnc., 418 U.S. 323, 345 (1974). The decision Professor Franklin cites does not mention a single other case making such a finding. See Dameron v. Washington Magazine, Inc., 779 F.2d 736, 740-43 (D.C. Cir. 1985), cert. denied, 106 S. Ct. 2247 
In addition to this normative consideration, the Iowa study indicates that public figures are less likely than private plaintiffs to suffer special damages. ${ }^{134}$ A "substantial majority" of public-figure plaintiffs believes that their damage suits "achieved reputation-related objectives, even thougl they lost."135 Moreover, public-figure plaintiffs have repeatedly asserted that their primary imterest is im vindication, not money damages. ${ }^{136}$ The Scliumer bill, by making it much easier for tliese plamtiffs to correct the public record, but less likely to recover damages they rarely suffer, does not represent a serious imposition.

Thus, Professor Franklin's concern that "damage cases involving public plaintiffs will virtually disappear" if the defendant's option were enacted $^{137}$ is beside the point. Little actual loss will go uncompensated

(1986). In any event, although the court did not reach the question, 779 F.2d at 743 , it seems likely that Dameron, an air traffic controller, was a public official under current law. Moreover, the story of an air crash is plainly a matter of great public concern, as to which Professor Franklin suggests the defendant's option may be appropriate. See Franklin, supra note 3, at 840-42.

Thus, in criticizing the Schumer bill for depriving "low-level public officials and involuntary public figures" of damages, Franklin, supra note 3, at 840, Professor Franklin is aiming at the wrong target. The problems he identifies stem from overly broad definitions of public officials and should be addressed directly. Although statutory redefinition of these terms might unduly complicate a new declaratory judgment statute, redefinition will be far easier to accomplish, either legislatively or judicially, if the stakes in libel litigation are sharply reduced by adopting the defendant's option.

Professor Franklin also criticizes the Schumer bill because the defendant's option is not limited to "statements that implicate self-governance." Id. at 840 . Particularly where public figures such as movie stars who desperately seek publicity are concerned, "self-governance" is too narrow a standard. If Hollywood sex lives figure too prominently in the supermarket tabloids, as suggested by Professor Franklin's references to the Enquirer and Globe, see id. at 838-39, the appropriate solution might be to define privacy rights as prohibiting such offensive discussion, whether it is trne or not. But see Zimmerman, Requiem for a Heavyweight: A Farewell to Warren and Brandeis's Privacy Tort, 68 CORNELL L. REv. 291, 364 (1983) (urging reliance on "social evolution" rather than the law of privacy to reduce "our excessive taste for personal details").

Given all of the justifications for the defendant's option, the interests of the small groups of plaintiffs cited by Professor Franklin seem minimal. The fact that the public figure concept may need some redefinition does not disqualify it from any use in the meantime. Whatever the outcome of this debate, the argument in the text clearly applies to public figures and to all elected officials and high-ranking appointees.

134. Bezanson, Libel Law, supra notc 2, at 228, 231.

135. Id. at 231 .

136. See, e.g., S. 1979, 1985-86 Cal. Leg., Reg. Sess. $\$ 1$ (legislative finding that the libel plaintiff "is rarely interested in monetary redress, but rather seeks vindication of his or her reputation").

Lawmakers, themselves public figures, are entitled to rely on these assertions, notwitlstanding Professor Franklin's characterization of them as "self-serving." Franklin, supra note 3, at 827, 837. Apparently, Professor Franklin does not credit admissions against interest. Even police officers suing to clear their names after accusations of brutality commented, " '[We're] not going to get any money out of them. . . We want our names cleared." E. Pell, THE BIG ChILl 186 (1984).

Whether such statements are self-serving or not, in light of so many consistent statements from such a wide range of plaintiffs, it is fair to take them at their word. In any event, damages are sought by public figures today primarily to cover their costs of suing or to punish or intimidate defendants. The former goal is served directly by the attorneys' fee-shifting provision of the declaratory judgment proposals. The latter insufficiently justifies a system with such enormous social costs.

137. Franklin, supra note 3, at 837 (footnote omitted). 
and reputational objectives will be better served. Moreover, defendants, particularly prominent and profitable national media organizations, may well conclude in some cases that the potential reputational injury of losing a libel suit justifies risking the slight chance of a damage award in return for the protection of the actual-malice defense. Under the Schumer bill, if both parties wish to take this course, it remains open. Given the obvious driving force of pride $m$ all libel litigation, defendants may not so readily accept the high risk of losing a strict-liability truth action as Professor Franklim assumes.

In any event, a declaratory judgment reinains a tremendously useful remedy to a public figure. It represents a formal judicial vindication of the plamtiff's reputation. Adding dollars to the declaration does not make it any more "useful," except perhaps to attract publicity for the fact of vindication - hardly an appropriate function for damages. ${ }^{138}$ By limiting the defendant's option to public-figure plaintiffs, the Schuiner bill focuses on plaintiffs who least frequently win damages and who least need or deserve monetary recompense. The Schumer bill does not, as Professor Franklin imphies, "den[y] the existence of harm in libel cases." 139 Rather, the bill realistically seeks to combat that harm by ensuring that truth is ascertained as promptly as possible.

\section{Fairness to Defendants}

Professor Franklim repeatedly suggests that the defendant's option is tantamount to an "absolute privilege for falsehood"140 that would allow "citizens" to be "defamed at will without effective recourse,"141 and that irresponsible publishers could "escape all liability for whatever harm they may impose by their use of deliberate falsehoods."142 Professor Franklin is wrong. The Schumer bill would foster just the opposite result by imposing a system of strict liability on defendants. Under the Schumer bill, as under Professor Franklin's proposal, defendants will lose a

138. I agree with Professor Franklin that requiring a defendant to publish a declaratory judgment would be an undesirable, though perhaps not unconstitutional, intrusion into the editorial process. Id. at 827-28; Franklin, Good Names, supra note 1, at 33-34, 42-43; see Miami Herald Publishing Co. v. Tornillo, 418 U.S. 241, 258-59 (Brennan, J., concurring). Any attempt to suppress the news of a libel defeat will likely be futile. A defendant's competitors, in the same medium or another, could use the defeat to gain competitive advantage. See supra note 100 . The New York Times and Daily News would no doubt relish reporting the libel misfortunes of Rupert Murdock's Post, and vice versa. If one newspaper dominates a city, television and radio competitors would still benefit from reporting the paper's libel defeats. Even in small communities primarily served by a single newspaper or broadcaster, the growth of alternative communications technologies sucl as cable television and direct satellite broadcasting makes the prospect of suppression increasingly unlikely.

139. Franklin, supra note 3 , at 838 .

140. Id. at 844 .

141. Id. at 841 .

142. Id. at $841-42$. 
substantial number of declaratory judgment actions and frequently will lose even when they are not at fault. Since plaintiffs can evaluate the strength of truth claims better than malice claims prior to filing suit, plaintiffs' success rate in declaratory judgment actions will far exceed their current five-percent success rate in damage actions. ${ }^{143}$ Eliminating the malice defeuse is thus an enormous concession to plaintiffs.

Successful declaratory judgmeuts will also exact a large price on the reputations of defendants for accuracy. Professor Franklin essentially ignores the important normative and economic role that reputation for accuracy plays in keeping the press honest. Although he admits that hibel damages are not "necessary to provide responsible publishers with incentives to be careful," 144 Professor Franklin apparently believes that only the threat of damages will keep "irresponsible publishers" in line. That conclusion, like his argument that the "defendant's election reinoves any deterrent effect of hibel law,"145 is overstated and untenable.

Libel law, like other legal constraints, is not effective purely because of the threat of pumisliment. Common sense suggests that, as in other situations where unlawful conduct inay be expedient in the short term, the vast majority of people are persuaded to act lawfully not by the deterreut effect of remote and uncertam legal punisliment, but by a sincere desire to do what is right-the force of moral suasiou. Professor Franklin has recognized that " "[t]here is nothing more important to journalists and journalism than credibility. ..." ${ }^{146}$ Part of the attractiveness of the declaratory remedy is its rehance on the defendant's selfinterest in reputation. A defendant which knows that its reputation for accuracy will be sullied without regard to fault every time it makes an error is likely to be more careful than a publisher which knows that it is shielded by the actual-malice defense ninety-five percent of the time. A responsible publisher, believing that its reputation for accuracy attracts customers, measures the total "cost" of any judgment against it not just by the out-of-pocket expense, but also by the costs resulting from injured reputation and future lost sales. ${ }^{147}$ These "costs" are likely to reach a greater total under the more certam punisliment of the declaratory remedy than under traditional damage actions.

Professor Franklin focuses on the necessity of danage remedies to deter "irresponsible publishers"148 and points to Burnett v. National

143. See supra note 121 and accompanying text.

144. Franklin, supra note 3 at 839-40.

145. Id. at 839.

146. Franklin, Good Names, supra note 1, at 46 (quoting NewSWEEK, May 4, 1981, at 50).

147. See id. at 27-28.

148. Franklin, supra note 3, at 838-40. In addition to the "scandal press," Professor Franklin suggests that "irresponsible publishers" may include political or religious zealots and unethical local media outlets. Id. He does not, however, indicate his basis for concluding that irresponsible 
Enquirer, Inc. ${ }^{149}$ as a paradigm. But the irresponsible publisher, like the professional criminal, is unhikely to be deterred by a legal system with a five-percent conviction rate and sentences that are little more than a slap on the wrist administered years after the offense. ${ }^{150}$ Presumably, the social deviant has calculated that the incremental benefits of misconduct are greater than the margmal risk of punishment.

Moreover, if Professor Franklin's theory were correct, one would expect that expansion im the scope of libel defenses would lead to greater press irresponsibility. Yet there is no evidence to suggest that incidents of culpable press behavior have increased since New York Times expanded the media's shelter from damages. Nor does the Enquirer seem any less prone to scandal-mongering since Burnett. The threat of large legal fees and unpredictable damage judgments that will injure a carefully nurtured reputation chills the law-abiding publisher, not the irresponsible deviant who has already calculated that the distant costs of potential libel losses are outweighed by present circulation increases. ${ }^{151}$

Since the prospect of paying damages has a relatively minor deterrent effect on irresponsible press behavior, Professor Franklin's proposal making declaratory judgments available at the plaintiff's sole option would not substantially diminish the social costs of the present system. Responsible pubhishers would continue to face the risk of virtually unlimited damage judgments, direct monetary costs for defense, and loss of

behavior by publishers is sufficiently widespread to justify the costs of preserving plaintiff' absolutc right to seek damages of virtually unlimited amount. See supra notes 116-18 and accompanying text. While the behavior revealed in the Burnett case may be deplorable, the plaintiff there only needed the $\$ 200,000$ judgment to pay her lawyers. The media are not so evidently infected with venality, and the Enquirer's behavior is not so typical, as to justify rejection of the defendant's option for all publishers, responsible and irresponsible alike.

Professor Franklin does suggest that the defendant's option could be modified to allow recovery of special damages even where the option is exercised. Franklin, supra note 3, at 842, n.133.

149. 144 Cal. App. 3d 991, 193 Cal. Rptr. 206 (1983), appeal dismissed, 465 U.S. 1014 (1984).

150. See supra note 122 and accompauying text. Professor Franklin has described the ultimate damage aivards as "relatively small." Franklin, Good Names, supra note 1, at $5 \&$ n.23.

151. Professor Franklin's assertion that after Burnett, "we are seeing an increasing amount of litigation against organizations like the National Enquirer and Globe International," expresses a hope not a fact. Franklin, supra note 3, at 839. He suggests that plaintiff' five-percent success rate will rise in damage suits against "irresponsible publishers." Any such increasc, however, is unlikely to deter misbehavior, which is the essential justification for Professor Franklin's opposition to the defendant's option. The actual-malice defense is simply too high a burden for most plaintiffs to meet.

Nor do Professor Franklin's anecdotal examples, id. at 839 n.119, show that the Enquirer and Globe are significantly deterred by the threat of damages. Two of the cases were settled, and according to the Iowa Libel Research Project, in the ten to fifteen percent of libel suits that are settled, "usually" no money changes hands. Bezanson, Libel Law, supra note 2, at 228, 229. The defendants are obviously prolonging the other suits mentioned, while they continue publishing alleged "fabrications" about the lives of movie stars who avidly seck publicity from others and, with equal fervor, seek to control the content of all public discussion to conform to their carefully cultivated "images." 
customers and reputation. ${ }^{152}$ Under the Franklin proposal, there is a significant likelihood that others-perliaps plaintiffs tempted by jackpot damages or "guilty plaintiffs" whose real goal is a long and liarrassing suit-will choose the damage option. In five to ten percent of these cases it is likely that plaintiffs will contmue to win. Thus, the spectre of large damage judgments and legal fees, albeit somewhat smaller than the risk today, would remain under Professor Franklin's proposal. A prudent publisher would have to consider that risk, which would, as a result, continue to exert a substantial chilling effect.

Professor Franklin's 1983 proposal also undercuts the concern he now expresses about irresponsible publishers causing unrecompensed injury. There, he suggested that a defendant should be able to avoid all liability for damages, including special damages, simply by publishing a "reasonable retraction" at the plaintiff's request. ${ }^{153}$ This provision was consistent with the theory of the defendant's option since it would allow publishers to pretermit the damage action and avoid paying for the "liarm" they had allegedly caused, even through intentional falsehood. In return, the plaintiff would get a public correction of the record-the saine outcome as in a successful declaratory judgment action after exercise of the defendant's option. Professor Franklin expressed no concern in 1983 that irresponsible publishers would abuse the retraction option that he offered. His present concerns that irresponsible publishers will abuse the defendant's option ring hollow. ${ }^{154}$

Professor Franklin does take some account of this problem by pro-

152. Although Professor Franklin's proposal would bar punitive damage awards, general damages, which he would allow, can include virtually unlimited amounts for emotional injury. See supra notes $45,114,117-18$ and accompanying text. Current trends in jury verdicts for intangible injuries in other torts make this prospect no less chilling than the threat of punitive dainages.

153. Franklin, Good Names, supra note 1, at 42 ("[T]he plaintiff will lose ... the right to bring a damage action upon defendant's publication of the ... retraction."); id. at 43-44 ("If the defendant responded [to a retraction demand] with a reasonable retraction, the plaintiff would be foreclosed from pursuing either [a dainage or declaratory judgment] action.").

154. Professor Franklin's proposed statute would inake retraction prior to filing of suit a complete defense only to a declaratory judgment action. POLRA, supra note 15, § 2(b); Franklin, supra note 3, at 816-17.

Professor Franklin now reinterprets his 1983 statements in seeking to counter the argument in the text. See Franklin, supra note 3 at 816 n.31. The record speaks for itself, however. See supra note 153. Moreover, Professor Franklin's criticism begins with a misreading of this Cominent. I do not say that he is "a past supporter of a defendant's option." Franklin, supra note 3, at 816 n.31. My point is more subtle. In 1983, he indicated that a "reasonable retraction" would foreclose relief even where the plaintiff suffered special damages or the defendant intentionally lied. That is inconsistent with his present arguments against the defendant's option, which focus on loss of special damages and lying defendants.

Professor Franklin also takes my words out of context in saying that I "assert that "expansion in the scope of libel defenses would lead to greater press irresponsibility.' "Id. at 840 n.123, quoting supra, at 872. He omits the essential qualification that precedes the words he quotes: "[I]f Professor Franklin's theory were correct, one would expect that expansion...,", etc. I go on to say that the facts do not support that expectation, arguing that Professor Franklin's theory is therefore wrong. 
posing adoption of the Enghish rule with respect to attorneys' fees both in damage actions and in his declaratory judgment proposals. ${ }^{155}$ Although the Enghish rule would tend to discourage guilty plaintiffs from pursuing hibel actions, a serious chilling effect would persist because Professor Franklin would allow an unsuccessful plaintiff to escape paying the defendant's legal fees if the plaintiff had a "reasonable chance for success" in bringing a declaratory judgment suit or a damage action where the plaintiff "sustained special damages."156

The "reasonable chance" standard is so broad that it will not change the risk calculated by prudent publishers. A careful defendant, or a publisher's reasonable insurance company, will have to assume that every losing plaintiff will claim a "reasonable chance of success." These claims will then have to be litigated, with the plaintiff's state of mind in bringing suit at issue and even his attorney's advice presumably subject to discovery. ${ }^{157}$ A "reasonable chance of success" is not a very difficult standard for a plaintiff to meet, particularly if his attorney cooperates in recalling advice given prior to suit. American judges, reluctant to award fees against an unsuccessful plaintiff, inay rarely allow a defendant to recover fees under Professor Franklin's proposal. ${ }^{158}$ The only suits likely to be

155. POLRA, supra note $15, \S 4$; Franklin, Good Names, supra note 1, at $38-39,42,43$; Franklin, supra note 3 , at 842-44.

156. POLRA, supra note 15, § 4(b)(1)-(2); Franklin, supra note 3, at 843, 842; Franklin, Good Names, supra note 1, at 39, 43. The "special damages" limitation is discussed infra note 158.

157. Difficult as it now is for plaintiffs to prove whether a defendant published a falsehood with a culpable state of mind, it would be more difficult for a defendant to prove the plaintiff's state of mind in bringing a libel suit. Some objective evidence, such as a reporter's notes or drafts of a story, is generally available to prove a defendant's state of mind. Other claims may be tested by questioning interviewees and editors about the process of newsgathering and editing. With respect to a plaintiff's basis for bringing suit, however, the only likely witnesses would be the plaintiff and the plaintiff's lawyer. Both have a strong incentive to tell the "right" story, and their testimony cannot likely be challenged by objective evidence such as third-party testimony or contemporaneous documents. In any event, a "reasonable chance of success" could be honestly claimed in any nonfrivolous suit.

Although Professor Franklin asserts that "the test is objective and not based on what an attorney might advise," the language of his proposal makes no such distinction. Compare Franklin, supra note 3, at 842 n.135 with POLRA, supra note $15, \S 4$. It hardly seems fair to punish a plaintiff who filed suit based on an attorney's overly optimistic advice. As a practical matter, the attorney's advice will be admitted in the form of argument to the court, if not in testimony.

158. Professor Franklin does limit the escape from fee shifting in damage actions to plaintiffs "who sustained special damages." POLRA, supra note $15, \S 4(\mathrm{~b})(1)$; see Franklin, Good Names, supra note 1, at 38-39. This limitation, however, does not significantly mitigate the problems described in the text. Presumably, whether a plaintiff "sustained special damages" is decided by looking at the complaint. If special damages were pleaded in good faith, fees should not be awarded. Thus, plaintiff' lawyers would be invited to plead creatively and to allege at least some small amount of actual pecuniary loss. The good faith of such a claim would be difficult to test, and challenging it would result in more undesirable "post-litigation litigation."

Moreover, the distinction that Professor Franklin draws, between plaintiffs who allege special damages and those who allege only presumed or general damages, is unpersuasive as a basis for deciding the fee-shifting issue. The reason that general damages are allowed in libel actions is 
weeded out are the patently frivolous. Enough nonfrivolous suits will remain to exert a chilling effect.

Yet Professor Franklin criticizes the Schumer bill's attorneys' fees proposal because it contains an "open-ended" provision permitting the court to disallow fee shifting "if there is an overriding reason to do so."159 This provision, however, is no more "open-ended" than Professor Franklin's "reasonable chance of success" proposal. Indeed, the "overriding reason" provision, by its language, imposes a higher standard to disallow fee shifting than "reasonable chance," and so should be applied less frequently. ${ }^{160}$

Professor Franklin also criticizes the Schumer bill's provision that attorneys' fees may not be awarded against a defendant that has taken reasonable care to avoid the publication of a libel or that published a retraction within ten days after service of the complaint. ${ }^{161}$ Although this exception would in a sense reinject the issue of the defendant's state of mind into the declaratory judgment action, ${ }^{162}$ on balance it appears necessary. First, the standard imposed is an objective one: "reasonable efforts to ascertain" accuracy. Second, a defendant might not raise the issue at all if the plamtiff's fee claim is relatively low. Third, there is some question whether, under the first amendment, a defendant can be forced to pay the plaintiff any money absent a showmg of fault. ${ }^{163}$ Last,

precisely because proving special damages, as opposed to pleading special damages, is considered to be extremely difficult. See R. SAcK, supra note 15, at 345-49. It is illogical to require those who may have suffered severe nonpecumary injury to bear the risk of having to pay defendants' attorneys' fees.

159. See Franklin, supra note 3 at 842; the Schumer bill, supra note 5, reprinted in Franklin, supra note 3 , at $832-35, \S 4(1)$.

160. The "overriding reasons" that would permit a court to disallow fees would be limited to such factors as extreme disparity in the wealth of the parties. For example, if a police officer or other low level public official were to lose a job because of a false report by a profitable television station, but were unable to prove actual malice, it might be unduly harsh to require the plaintiff to pay the defendant's attorneys' fees.

161. See Franklin, supra note 3, at 843-44; the Schumer bill, supra note 5, reprinted in Franklin, supra note 3 , at $832-35, \S 4(2)$. The argument that unnecessary injury would be caused by precluding attorneys' fees upon publication of a retraction after the complaint is filed has considerable force. Moreover, this provision may provoke undue haste in filing suits. Accordingly, it would be preferable if the retraction exception were changed to provide that the time for publishing a retraction runs from the date when that plaintiff demanded a retraction or the date of filing suit, whichever is earlier.

To avoid unfairness to the defendant, a retraction demand would have to specify the facts on which it was based. Professor Franklin proposes that the defendant be allowed a reasonable time to consider the demand; this may be more appropriate than a rigid 10-day limit. See Franklin, supra note 3 at 844 n.143; POLRA, supra note $15, \S 2$ (b).

162. In damage actions, to which the fee-shifting provisions of the Schumer bill would also apply, state of mind will continue to be an issue irrespective of the standards governing fee shifting.

163. Professor Franklin has suggested that if some fault must be shown before a libel defendant is forced to pay fees, it could be implied from an unreasonable refusal to retract. Franklin, supra note 3, at 822; Franklin, Good Names, supra note 1, at 48 . Aside from the practical problems of requiring a plaintiff to demand a retraction before filing a declaratory judgment action, this suggestion opens the unfortunate possibility of a new tort for unreasonable refusal to retract. A 
to the extent that discovery into the editorial process is necessary, it need not occur until after there has been a judgment of liability. Bifurcated discovery would avoid editorial process inquiry in all cases in which defendants win. When plaintiffs win, fees often will not be an issue because they are relatively modest in amount, because the defendant realizes it was at fault, or because soine compromise can easily be worked out given the relatively modest stakes.

\section{Practicality of Operation and Feasibility of Adoption}

The political attractiveness and practicality of implementation may well be crucial eleinents in the adoption and ultimate success of any libel reform. A proposal which makes use of existing legal and procedural structures is likely to win public acceptance more easily and to work inore smoothly than one which requires major realignment of law and procedure. A reform proposal also should give consideration to political realities if it is to become more than a theoretical exercise.

Except for the absence of dainages, litigation of declaratory judgment actions under the Schumer bill would follow the same procedures as other statutory tort-type remedies. Suit inay be brought "in any court of competent jurisdiction," 164 which would include both state trial courts of general jurisdiction ${ }^{165}$ and federal district courts in diversity cases. ${ }^{166}$

statute making unreasonable refusal to retract the basis for an award of attorneys' fees could be interpreted as establishing a duty to publish reasonable retractions. A court might well imply a common law right of action for damages from violation of the legislatively imposed duty. Although such an action might well be unconstitutional, the prospect is sufficiently disturbing to argue against Professor Franklin's suggestion. See supra note 138; Miami Herald Publishing Co. v. Tornillo, 418 U.S. 241 (1974).

164. The Schumer bill, supra note 5, reprinted in Franklin, supra note 3, at 832-35, § 1(a)(1).

165. The bill's express jurisdictional language makes it mandatory for state courts of competent jurisdiction to hear these declaratory judgment claims.

166. 28 U.S.C. $\S 1332$ (1982). The Schumer bill might also be read to confer federal court jurisdiction over all declaratory judgment libel suits because the claim "arises under the . . . laws ... of the United States." 28 U.S.C. $\S 1331$ (1982). The same theory would also allow removal, under 28 U.S.C. $\$ 1441$ (b) (1982), of declaratory judgment suits commenced in state court. Since common law libel claims arise under state, not federal law, libel cases currently must be brought in state courts unless diversity exists. If the Schumer bill is construed as making libel a federal question, however, it could shift the locus of libel litigation, raising the prospect of overburdening the federal courts with claims whose substance will be largely a matter of state law.

The general federal declaratory judgment statute does not give federal courts jurisdiction over declaratory judgment actions unless diversity exists or a federal question appears on the face of a "well-pleaded complaint." 28 U.S.C. § 2201 (1982); Skelly Oil Co. v. Phillips Petroleum Co., 339 U.S. 667 (1950); see also Franchise Tax Bd. v. Construction Laborers Vacation Trust, 463 U.S. 1 (1983) (applying Skelly Oil to preclude removal of state declaratory judgment action). The Schumer bill's authorization of declaratory judgments might be construed analogously as "procedural only," Aetna Life Ins. Co. v. Haworth, 300 U.S. 227, 240 (1937), but that result is uncertain in light of the bill's avowed purpose of "establishing a new cause of action," see supra note 5 , and not merely filling a procedural gap. It would be preferable to eliminate such uncertainty by providing that original and removal federal question jurisdiction is not available for the new cause of action. 
Since the Schumer bill makes no provision for special discovery rules or other procedural changes, normal court procedures would apply. The parties are free to conduct discovery to the extent that each finds it appropriate in hight of the value that each attaches to protecting its reputation. The elimination of damages will greatly reduce pressure to obtain or avoid an enormous judgment by means of massive discovery, multiple motions, and other litigation strategies. ${ }^{167}$ The prospect of having to pay the winner's attorneys' fees also should tend to limit these practices.

Professor Franklin proposed in 1983 that a plaintiff would have to present his or her evidence of falsity to the defendant, seeking a retraction or correction. ${ }^{168}$ Only if this forced negotiation were unsuccessful could the plaintiff file a declaratory judgment action. Further, the plaintiff would be limited to presenting in court "essentially" the same evidence that had been shown to the publisher earher. ${ }^{169}$ No discovery would be permitted at any stage in the declaratory judgment action. ${ }^{170}$

Professor Franklin now recognizes that the preaction conference and the limitation on trial proof that he proposed in 1983 were impractical. Instead of mandating them in all actions, he would now use attorneys' fees as incentive to encourage the conference and limit trial proof. ${ }^{171}$ While continuing to urge elimination of discovery, he concedes that allowing it "will probably not cause fatal difficulties."172

Professor Franklin's 1983 proposal for mandatory preaction conferences was unnecessary and likely counterproductive. Libel victims today frequently contact the media and try to resolve their disputes without lawyers or lawsuits. Many plaintiffs decide to sue only when they are rebuffed. ${ }^{173}$ Any declaratory judgment reinedy would encourage defendants to histen inore carefully to such complaints because the defendant would be threatened with a no-fault finding of liability. Forcing the parties to talk, however, can only increase friction.

The himitations that Professor Franklin proposed in 1983 on discov-

167. Since actual malice will not be an issue, that entire area of discovery and proof at trial will be eliminated. Although cases like Westmoreland and Sharon demonstrate that discovery and trial on truth alone can be extraordinarily complex, they are certainly the exceptions. In most cases, truth will be no more complex an issue than malice and may be much simpler. In every case, eliminating malice will necessarily make that case simpler than it otherwise would be. In the discovery that does occur, plaintiffs will presumably seek to learn what evidence of truth the defendant plans to use, and defendants will want to probe for proof of falsity which the plaintiff possesses. Each party also will want to search for exculpatory evidence within the other party's knowledge.

168. Franklin, Good Names, supra note 1, at 41-42.

169. Id.

170. Id. at 44 .

171. POLRA, supra note $15, \S 4(\mathrm{~b})(2)-(\mathrm{b})(3)$; Franklin, supra note 3 , at 814-15.

172. POLRA, supra note $15, \S 2$ (c); Franklin, supra note 3 , at 829.

173. Cranberg, supra note 2 , at 221 . 
ery and proof at trial would have made the declaratory judgment action too risky and hence virtually unusable. For example, absent discovery, the defendant would not be required to tell the plaintiff what unpublished evidence of truth the publisher has. A publisher could use this loophole to destroy a plaintiff's reputation by surprising the plaintiff with devastating proof of truth at trial. ${ }^{174}$ Furthermore, since the plaintiff would have revealed his entire case at the preaction conference, the publisher could prepare to meet that evidence at trial; the plaintiff could only speculate as to the evidence he would face. Although the publisher could surprise the plaintiff with secret witnesses or documents, the plaintiff would be limited, even in rebuttal, to "essentially the same evidence presented to the defendant [with the retraction deinand] and nothing new."175

Professor Franklin's current proposal eliminates the ill-advised preaction conference and modifies the absolute limitations on trial evidence. The absence of discovery, however, still places plaintiffs at considerable risk in a trial-by-surprise. Plaintiffs' lawyers may well advise clients to avoid Professor Franklin's declaratory judgment action altogether, since it would pose too great a risk against a well-counseled defendant. ${ }^{176}$ Limiting discovery poses still a further problem for both parties, as well as the public. Such a limitation undercuts the fundamental purpose of the declaratory judgment trial: to determine the "truth" and to give the "truth" a judicial imprimatur. ${ }^{177}$ If a court judgment is

174. The threat of a damage action would not necessarily induce publishers to reveal evidence prior to filing suit, since the same evidence would probably inake out a inalice defense.

175. Franklin, Good Names, supra note 1, at 42 . Apparently, under the 1983 proposal, even if the plaintiff found a lost witness or uncovered a forgotten document, the defendant could prevent their use at trial.

176. Professor Franklin argues that discovery is unnecessary because plaintiffs "usually do not use it to get information on falsity" and have "ample proof of falsity." Franklin, supra note 3, at 828, 829. These assertions, based on a private conversation, are probably incorrect. In my own experience, plaintiffs frequently use discovery to obtain evidence of falsity. Perhaps Professor Franklin is confused by the fact that discovery relating to actual malice under current law necessarily subsuines discovery on falsity, since actual malice requires proof of knowing or reckless falsehood. Eliminating malice will eliminate the need to discover the defendant's intent, but defendants will continue to possess information probative of falsity.

In any event, Professor Franklin errs in dismissing the significance of another essential function of discovery in libel cases-to learn what evidence of truth the defendant may have so that the plaintiff can be prepared to rebut it at trial. If the plaintiff's best friend is going to testify against him, it inay profoundly affect both the plaintiff's decision whether to go to trial and his trial preparation. Professor Franklin would deny the plaintiff that knowledge in the hope that defendants would find it in their self-interest to reveal it. See id. at 829. But discovery is such an important aspect of the judicial truth-finding function that it seems unwise to experiment with it. By lowering the stakes in libel actions, however, declaratory judgments will reduce the parties' inclination to undertake inassive discovery. See supra note 167 and accompanying text.

177. Discovery is frequently used to learn of evidence helpful to the discovering party's case. See supra note 167. Absent discovery, either party could win at trial even though it was aware of evidence which, had it been produced in discovery, would have changed the outcome. 
to be rendered on the issue of truth, it should be a judgment reached with the benefit of the full panoply of procedural devices developed by the courts to ascertain the truth. ${ }^{178}$

Another important practical concern is whether national libel reform legislation is appropriate. ${ }^{179}$ Congressional action is warranted, at least in dealing with public-figure damage suits, punitive damages, and the statute of limitations. ${ }^{180}$ The problems with the present system in these respects are sufficiently serious to warrant prompt improvement; reform is more hikely to come from Congress than the state legislatures. Even though libel is a state-created cause of action, the common law tort has now been so altered and constrained by application of federal constitutional standards that rationalizing the system on a nationwide basis is essential. Congress also may be less prone to antipress sentiment that could unbalance a reform proposal. ${ }^{181}$ With the liability insurance crisis now focusing attention on broad reform of the tort system im Congress and many state legislatures, ${ }^{182}$ it is a propitious time to implement hibel reform as well. Nor is pursuit of federal legislation inconsistent witli reform at the state level. Alleviation of the crisis even im a few states should improve the present situation. The Schumer bill has already been used as a model for bills introduced in the Califorma and Maryland legislatures. ${ }^{183}$ Further state activity should be encouraged.

The Schumer bill represents a good starting point for libel reform because it deals agressively with public figure damage suits where a consensus for change is most likely to develop. The Schumer bill proposes significant changes affecting private-figure suits as well, but it does notim contrast to Professor Franklin's proposal-seek to raise the private-

178. If a less formal proceeding is desirable, the outcome should not be labeled as a court judgment. Professor Franklin's assertion that "discovery is little used in the criminal justice system," id. at $829 \mathrm{n.84}$, ignores the existence of grand juries, which are extraordinarily powerful discovery tools for the prosecution, as well as the constitutional and statutory rights of defendants to compel production of potentially favorable evidence. See, e.g., 18 U.S.C. $\S 3500$ (1982); FED. R. CRIM. P. 15, 16, 26.2; Brady v. Maryland, 373 U.S. 83 (1963).

179. See Franklin, supra note 3 , at 818-19.

180. Professor Franklin agrees that congressional action on the statute of limitations issue might be appropriate. Id. at 819 n.36.

181. See supra note 13; Franklin, Good Names, supra note 1, at 8-10; Smolla, "Where Have You Gone, Walter Cronkite?': The First Amendment and the End of Innocence, 39 ARK. L. REV. 311 (1985).

182. See, e.g, Pear, Administration Submits Plan to Reduce Damage Awards, N.Y. Times, May 1, 1986, at B9, col. 1; Gov. Cuomo Names Panel to Study Insurance Rises, N.Y. Times, Jan. 14, 1986, at B2, col. 1. See also Sugarman, Doing Away With Tort Law, 73 CALIf. L. Rev. 555 (1985) (advocating state and congressional legisiation and administrative action to create a social insurance system); Pierce, Institutional Aspects of Tort Reform, 73 CALIF. L. REV. 917 (1985) (attempts at legislative reform face crowded agendas, opposition from powerful vested interests, and the dangers of compromise legislation).

183. S. 1979, 1985-86 Cal. Leg., Reg. Sess. (introduced by Sen. Lockyer); H. 1255, Md. Gen. Ass. 1986 Sess. (introduced by Del. Rosenberg). 
figure liability standard from negligence to actual malice. While applying the actual-malice standard to all libel actions may be intellectually sound and would bring welcome consistency to the law, ${ }^{184}$ it is a change that is unlikely to command inuch public support. Judicial reaction to Gertz's mvitation to fashion state liabihty rules for private plaintiffs slows that the neghigence standard is widely believed appropriate. ${ }^{185}$ Seeking to raise that standard in an initial libel reforın package will generate strong opposition and inay lead to rejection of reforin altogether. ${ }^{186}$

\section{CONCLUSION}

Professor Franklin condeinns the Schumer bill as politically unattractive primarily because he clains that it would allow " irresponsible publishers' to escape all liability for whatever liarın they may inpose by their use of deliberate falselıoods." 187 If this were wliat the bill proposed, criticisin inight be justified. But the Scliumer bill does nothing of the kind. Although it would give defendants the opportunity to avoid damages by invoking the conversion option, the Scliumer bill would also subject defendants to strict liability for false statements. This strict-liability standard means that defendants will lose "libel suits" frequently, instead of winning ninety to ninety-five percent or more as they do today. A defendant which makes an error will risk fairly certain injury to its repu-

184. Compare Franklin, What Does "Negligence" Mean in Defamation Cases?, 6 Comm./ENT. L.J. 259 (1984) (negligence standard is in practice the equivalent of strict liability) with Bloom, Proof of Fault in Media Defamation Litigation, 38 VAND. L. REV. 247 (1985) (negligence standard works reasonably well and adequately protects press).

185. See Bloom, supra note 184, at 335 ("The great majority of courts that have addressed the issue to date have adopted a negligence standard."); Franklin, supra note 184, at 264-65 (1984) (at least 26 states, the District of Columbia and federal courts interpreting the law of three additional states have applied negligence standard); R. SACK, supra note 15, at 250, 255-60 (as of 1980, six states "may have adopted" actual-malice standard for matters of public interest and seven others have indicated an intermediate standard might apply).

186. Since the Schumer bill would allow defendants to convert damage actions into suits for declaratory judgment, the question might be raised whether it violates the due process clause by depriving plaintiffs of the right to damages. The answer is no. First, the Supreme Court has held that an individual's interest in reputation is not "liberty" or "property" protected by due process. Paul v. Davis, 424 U.S. 693, 710-12 (1975). Accordingly, prospective deprivation of a right to sue for libel damages does not violate the due process clause. Second, Congress and the state legislatures have broad powers to fashion new remedies to rcplace common law damage actions, particularly when the new remedy would be more prompt and certain than the damage action in most cases. The classic example is the replacement of common law negligence actions with workers' compensation statutes. See, e.g., Tipton v. Atchison, Ry. Co., 298 U.S. 141 (1934); Cudahy Packing Co. v. Parramore, 263 U.S. 418 (1923); New York Central R.R. Co. v. White, 243 U.S. 188 (1917).

Congress has the constitutional power to enact libel reform legislation, even though libel law historically has been left to state control. Congress could act either under the Commerce Clause, at least with respect to news media which affect interstate commerce, or under section 5 of the fourteenth amendment. Since the first amendment is incorporated into the fourteenth, Congress has the power to "enforce" the former "by appropriate legislation," such as the Schumer bill.

187. Franklin, supra note 3 , at $841-42$. 
tation for accuracy and a courtroom loss that can be exploited by competitors.

Far from freeing libel defendants from all restraint, the defendant's option is crucial to the practical effectiveness of any declaratory remedy. At least with respect to public figures, granting plaintiffs the exclusive choice of the declaratory judgment route would unfairly tip the balance of interests against the press and ultimately diminish robust public debate. Professor Franklin's legislative proposal would add a powerful new weapon to "the plaintiff's arsenal" against the media, ${ }^{188}$ while doing relatively little to ameliorate the chilling effect of damage actions. ${ }^{189}$

Professor Franklin's criticism focuses too narrowly on the perceived interests of the parties im libel suits. The first amendment tells us that the general social interest in the quality of public debate is of paramount importance. By undervalumg the social costs of public-figure damage actions-the transaction costs, the chilling effect, and the imterest in the flow of truthful information about the accuracy of facts at issue in libel cases-Professor Franklin overstates the case against the defendant's option.

The primary social imterest in a libel action is to correct a proven falselood, not to reveal the defendant's state of mind. The stated desires of most public-figure plaintiffs are consistent with this social interest. Plaintiffs emphatically assert that they want only to set the record straight and have little interest in damages except as a means to that end. Accordingly, no substantial purpose is served by spending thousands and even millions of dollars to discover whether the defendant lied, acted carelessly, or was merely unlucky. Allowing public figures an unfettered choice provides too great a temptation to perpetuate the damage action with its possible jackpot of almost limitless general damages. Professor Franklin's proposal may lessen current libel problems somewhat, but the chilling effect and other social costs will remain excessive.

Nor are general damages for libel essential to keep irresponsible publisliers in line, as Professor Franklin maintains. A publisher determined to build an audience with titillating untruths is only minimally mhibited by the slight prospect of a damage judgment of uncertain amount years later. Witlı defendants sucli as CBS, Time and The Washington Post involved in celebrated cases, it is evident tliat present law does not target only "irresponsible publishers." The likelihood of

188. Id. at $817-18$.

189. Perhaps the five-percent success rate of current libel plaintiffs has distorted our perception of the fairness of the system. Because that rate is so low, allowing a declaratory judgment might appear only to give plaintiffs a reasonable opportunity to win cases. But for the reasons discussed in the text, creating a declaratory judgment remedy without a defendant's conversion option would tip the balance much too far in plaintiffs' favor. 
liability, or at least of ligh defense costs, does chill the aggressiveness of responsible journalists. Allowing defendants the option to avoid damages in return for their incurring a much higher frequency of liability, and a concomitant loss in reputation for accuracy, is a fair and necessary tradeoff for the parties in light of social interests, particularly the first amendment interest in robust debate. 